\title{
A REVISION OF THE INDIAN SPECIES OF OBERONIA (ORCHIDACEAE)
}

\author{
R. ANSARI \& N.P. BALAKRISHNAN
}

Botanical Survey of India, Southern Circle, Coimbatore 641 003, India

\begin{abstract}
SUMMARY
A taxonomic revision of the orchid genus Oberonia Lindley for India with 41 species is presented. Two new species, $O$. balakrishnanii and $O$. nayarii are established. Oberonia bisaccata and $O$. rangannaiana are considered conspecific with $O$. platycaulon and $O$. chandrasekharanii respectively. Oberonia acaulis and $O$. myriantha, which were treated as synonymous to each other by earlier workers, are now proved to be distinct species based on detailed study of the column.

The species are grouped under six sections after modifying the classification proposed by Seidenfaden (1968) to suit the Indian plants. Dichotomous keys are provided for all taxa. The geographical distribution of each section within the country is discussed. All species are illustrated.
\end{abstract}

\section{INTRODUCTION}

The genus Oberonia was first described by Lindley in 1830 who dedicated it to Oberon, the mythological king of fairies. While establishing the genus, Lindley recognised 13 species of which three were from India. Subsequently, many new species were added to the genus by different workers. Wight (1851) contributed six species, all from India. In 1859 Lindley revised his first list of Oberonia species incorporating all the newly described plants, thus increasing it to 50 numbers. Later in 1888, while treating the genus for Flora of British India, Hooker $f$. included 41 species. Of these, 21 species were considered to occur within the present boundaries of India. Since then a large number of regional floras appeared wherein further details on the distribution of these species were made available.

As far as the Indian species of Oberonia are considered, apart from the local floras and the few taxonomic works on orchids of restricted regions such as those of King \& Pantling (1895 and 1898), Duthie (1906), Santapau \& Kapadia (1966), Abraham \& Vatsala (1981), Ansari et al. (1982), Joseph (1982), Kataki (1986), etc., there is no consolidated work giving detailed descriptions of all the species. Seidenfaden (1968) while revising the genus Oberonia of Mainland Asia included all the Indian plants known at that time; but it covers wider geographic regions. Since then, during the past 20 years of intensive explorations, many new species were added and some alien species were recorded from India. Pradhan (1979) gave a comprehensive account of the Indian species of Oberonia, but the descriptions were mostly adopted from other published works and gives little importance to their taxonomy. Based on all earlier works and records, Jain \& Mehrotra (1984) enumerated 44 species of Oberonia from India. 
The present work was started with the intention to make an up-to-date consolidated account of the Indian species of Oberonia. The herbarium specimens available in all the major Indian herbaria have extensively been used for this work. Efforts have been made to examine pickled as well as live materials as much as possible to obtain details which will not be evident in the dried specimens. Specimens in the Kew Herbarium where the majority of the types of Indian plants are located, could not be studied. However, the microfiche and the duplicates of many of these types are available in the Indian herbaria. Although the possibility of error in duplicates of types are not excluded, it is only reasonable to accept them as identical with the types and hence they are invariably referred as types in the succeeding pages.

Detailed descriptions of 41 species of Oberonia recognised after analytical study of specimens and review of literature are provided in the present paper. Specimens of five species could not be examined due to the lack of specimens in the Indian herbaria. They are listed at the end of the systematic treatment. All the intraspecific variations noted are included in the description. Range of variations in the measurements of minute flower parts are excluded by providing an average of all the measurements taken unless when this difference is remarkably great. The species are arranged in the sequence as they are numbered in the keys. The citation of synonyms are minimised by restricting to the names as they appear in the works dealing with Indian plants under the genus Oberonia, excepting for basionyms.

Descriptions of all the species are supplemented by illustrations. Figures of similar parts are uniformly enlarged in all the species so that the size differences can readily be recognised. By attempting to do this two extremeties in the size of the figures have appeared, but the same magnification of all parts is considered advantageous for a comparative analysis of the plants.

Data for phenology and altitude are taken from collector's notes on the herbarium sheets. But in certain cases this is adjusted based on earlier published works, especially when the collections are insufficient. Distribution of each taxon is summarised after its description.

All specimens examined (microfiche excluded) have been listed alphabetically by locality and then by collector at the end of each species. The letters given in brackets after each specimen indicate the acronyms of herbaria where it is housed (for abbreviations of the herbaria, see under Acknowledgements). When the specimen cited is a type (or a duplicate of it) this is specified after the relevant herbarium.

Important aspects regarding taxonomy, nomenclature, distribution, etc. of certain species are discussed briefly under the corresponding taxon, wherever it is found necessary. Some important literature which was consulted during the course of this study but is sometimes not cited in the text, is listed at the end.

\section{MORPHOLOGICAL CONSIDERATIONS}

Habit - All species of Oberonia are herbaceous epiphytes. The plants may be erect or pendulous, but this character being not constant is not of any specific significance.

Stem - Oberonias, in general, are acaulescent plants with a group of distichous leaves arising from the base. A tendency for caulescent nature can be noted in certain species by the elongation of some upper internodes, but this feature often varies even within the same 
species. However, this elongation is constant and common to all the internodes in $O$. falcata and $O$. mannii. It can thus be concluded that the caulescent nature is of little value in the major grouping, but can be used as a minor character for delimiting species.

Leaves - The laterally compressed leaves in distichous arrangement forms the most readily obvious diagnostic feature of the genus excepting in plants of section I which are unique in having more or less terete leaves. In plants of section I to IV, an articulation can be seen near the base of each leaf and in such cases the leaves are deciduous. Plants of the other sections have persistent leaves.

Scape - Two forms of scapes can be distinguished among the plants of Oberonia. It may be either terete (or indistinctly so), or flattened and winged laterally with the reduced uppermost leaf often carried along with it to a certain distance.

Spike - The spike is thick and fleshy with closely adpressed flowers in $O$. pachyrachis, whereas in the other species it is rather thin bearing somewhat loosely arranged flowers. The aestivation of flowers on the spike may be spiral, verticillate or scattered. In certain species of section III, a definite portion at the apex of the spike will always remain sterile. However, in $O$. platycaulon the spike is dimorphous, being with or without a sterile portion.

Flowers - In Oberonia the flowers are minute. The largest flowers noted are in O. anamalayana measuring up to $5.25 \mathrm{~mm}$ long and $2 \mathrm{~mm}$ across. Flowers may be sessile or pedicelled, but this cannot be distinguished with certainty in all cases since the pedicel is continuous with the inferior ovary. Hence this is a fragile character for species delimitation.

Bracts - Each flower is supported by a bract. In certain instances, a single bract may bear two or three flowers in its axil, but this is not consistent in any species. In general, bracts are of little taxonomic value.

Sepals - Although the size, shape and margins of sepals are notably variable, their orientation in flower often forms a useful supplementary character for species differentiation.

Petals - The petals often exhibit specific consistency in their shape, margins, orientation, etc. In many cases they are useful for initial determination.

Lip - Although minor intraspecific variations are not uncommon, the lip is considered to be one of the most valuable structures for delimiting species. A great variation of lip forms is present in the genus, with specific consistency. Hence, in correlation with other supporting characters, lips offer valuable clues for drawing up the lines of affinities within the genus.

Disc - The disc on the lip may be indistinct, cushion-like, concave, saccate or tubular and its use in determining species is considered great. A peculiar form of disc is present in the lip of $O$. ensiformis where the lateral lobes are separated from the midlobe by an elongated mesochil.

Column - The column is the specialized reproductive structure, combining androecium and gynoecium, peculiar to Orchidaceae. Even though it has largely been used for classifying orchids at the generic level, its use in infrageneric categories was believed to be meagre. In Oberonia the column is a very minute structure and hence remained neglected or insufficiently studied in most of the cases. In the present work special attention is paid to this structure and in many cases it is found to be of great value in delimiting closely allied and doubtful species. The column, in general, is a cylindric or globose structure at the centre of the flower, bearing at the tip the stigma and the pollinia bearing cavity (clinandrium). The lid of the clinandrium, called operculum or anther cap, may be positioned either at the apex 
of the column or on the dorsal side and thus the clinandrium is said to be either apical or dorsal, respectively. The clinandrium is often surrounded by a wing which may be uniform throughout or more elongated near the stigmatic side with the undeveloped stigma lobe (rostellum) forming a protuberance at the middle.

Pollinia - As many pollinia as possible were examined for each species for studying their specific characteristics and they often provide additional taxonomic features.

Fruits - Fruit characters, for the majority of species, are uniformly similar and offer little help for identification with certainty and hence are excluded here.

\section{CLASSIFICATION}

Lindley (1859) grouped Oberonia into two major sections: Acaules having no stem and Caulescentes with an elongated stem. Hooker f. (1888) made it into four sections. His section Oberonia proper with 'very short' stem covered a majority of the species. Many plants which Lindley kept under Caulescentes were transferred to this section. Under the section Scylla, he included a single species where the stem is 'short or 0'. The section Myosurus, characterised by terete leaved plants, carried a single species, $O$. myosurus. Three plants which he considered to possess elongated stems were kept under the last section Caulescentes. Seidenfaden (1968) recognised nine sections for the species of Mainland Asia. He followed Schlechter (1911) and Holttum (1957) while considering the jointed nature of leaves as an important character for classifying Oberonia.

In the present work, the sections proposed by Seidenfaden are largely followed. However, the delimitation of sections is modified by merging and splitting some of his sections and in many instances the plants have been rearranged. These alterations were found necessary because the present work deals only with the Indian species and some additional species were added subsequently. So also the nature of column and disc were analysed in detail and these characters are extensively used for delimiting the species. Thus, the following six sections are outlined to suit the species available in India:

Section I - Seidenfaden included four species under his corresponding section I of which $O$. myosurus is present in India. Oberonia sulcata, which is suspected to be conspecific with $O$. langbianensis, is also included under this section. The plants of this section are unique in having terete leaves and hence, as Seidenfaden felt, it may form a natural entity. But the leaves are articulated at the base as in sections II to IV. In India, the section is restricted to the Himalayan region.

Section II - Oberonia pachyrachis is the only species included under this section, which stands isolated from the rest of the sections by the spiral arrangement of flowers on the fleshy spike. However, by the flattened scape the section shows its affinity to section III. Seidenfaden included $O$. maxima, $O$. proudlockii and $O$. orbicularis along with $O$. pachyrachis under his section II. Oberonia maxima has a terete scape and hence is kept here under section IV, whereas in $O$. proudlockii the leaves are not jointed as in sections V and VI. Since the specimens of $O$. orbicularis are not available in Indian herbaria, these could not be studied for the present work (see under excluded species).

Section III \& IV - These sections together are equivalent to the sections III and IV of Seidenfaden. He demarcated these sections based on the size of the leaves which is now 
found to be an undependable character for the purpose. Hence the plants in his section are rearranged in the present work mainly based on the scape form, which may be flattened or terete.

Section $\mathrm{V}$ - This section includes a single species, $O$. bicornis, which is characterised by the vertically raised lateral lobes of the lip which appear as two horns on either side of the column. The leaves are continuous as in section VI. This section corresponds to section VII of Seidenfaden.

Section VI - This section is analogous to section VI, VIII and IX of Seidenfaden. He formulated these sections based on the length of the stem. But this character is found futile in many cases for deciding the section with certainty, due to the reasons explained under morphological considerations. Hence all the three sections of Seidenfaden are brought under one section in this work. Oberonia falcata and $O$. mannii, where the caulescent nature is distinct and constant, are kept at the end of this section.

By suggesting these sections, no claim is made here that the plants are thus made into phylogenetic groups, as it will not be advisable to attempt such a classification based on the plants of a small geographic region. Instead, it is only aimed as a general practical aid in their identification, though these groups may later help to form a natural classification, since the plants exhibiting concurrent features will come together. However, in certain sections some odd ones also happened to be included, as it is inevitable in such taxonomic works.

\section{GEOGRAPHICAL DISTRIBUTION}

The genus Oberonia consists of about 300 species distributed from South Africa to Samoa through India, China, Burma, Thailand, Malesia, etc. In India, the number of species is believed to be 41 . Based on the centres of concentration of Oberonia species in India, two geographical regions can be earmarked as follows:

1) Western Ghats Region - All the 12 species included under section II, which is characterised by the jointed leaves and flattened scape, are present in this region. All of these, except the widespread species $O$. denticulata and the Sri Lankan species $O$. zeylanica, are endemic to Western Ghats. The occurrence of $O$. zeylanica in W. Ghats needs further confirmation (see under Systematic treatment). The plants of the other sections are very poorly represented here. From section IV only five plants are present in W. Ghats of which O. ensiformis is a widespread species. Oberonia arnottiana is frequent in W. Ghats but is very scarce in the Himalayan region. It can hence be considered that the present disjuncted distribution of $O$. arnottiana represents the remnants of a past widespread and more common species. Its closely related species $O$. wightiana is notably endemic to $\mathrm{W}$. Ghats. Cberonia thwaitesii is a Sri Lankan species of which occurrence in India is doubtful, whereas its allied species $O$. verticillata is endemic to W. Ghats. Thus the high percentage of endemism noted among the species of $\mathrm{W}$. Ghats points towards a successive speciation of the genus within this region through adaptations. It can also be assumed that the W. Ghats with its topographical and climatic variations enabled the population of these plants to become more heterogeneous. 
Among the continuous leaved (non-articulated) plants, only four species are available in this region. These include two endemics, viz. $O$. proudlockii and $O$. brachyphylla. Thus the total number of endemic species of Oberonia in W. Ghats region is 14.

2) Himalayan region - The Himalayan region harbours about 27 species of which only five are endemic ( $O$. angustifolia, $O$. lobulata, $O$. mannii, $O$. orbicularis and $O$. sulcata). Among these, $O$. sulcat $a$ is believed to be conspecific with the Vietnamese species, $O$. langbianensis. The presence of $O$. angustifolia and $O$. orbicularis needs confirmation. Among the remaining Himalayan plants only seven species $(O$. arnottiana, $O$. bicornis, $O$. denticulata, $O$. ensiformis, $O$. falconeri, $O$. recurva and $O$. rufilabris) extend their distribution towards the Peninsular region of India, whereas the remaining ones share their distribution with the countries bordering the Himalayan region. It can thus be presumed that the free spread of the species of Oberonia from the Himalayan region downwards is restrained by some natural barriers. Thus, the distribution of most of the species of the sections I, II, IV and VI within the country is confined to the Himalayan region.

\section{ACKNOWLEDGEMENTS}

We are grateful to Dr. M.P. Nayar, Director, Botanical Survey of India, Calcutta for kindly providing all facilities during the course of this study. We wish to express our gratitude to Dr. V.J. Nair, Scientist B, for the Latin diagnosis of the two new taxa. Dr. Gunnar Seidenfaden, Borsholmgaard, Denmark sent us all his publications which formed the prime guidance for our work. He was also very liberal to pass his views in several occasions. The work was rendered possible only through the kindness of the authorities of the following herbaria by putting their valuable specimens at our disposal for about three years and by providing facilities to work in their herbaria: Central National Herbarium, Calcutta (CAL); Regional Herbaria of Botanical Survey of India, Shillong (ASSAM), Dehra Dun (BSD), Allahabad (BSA), Poona (BSI), Port Blair (PBL), Jodhpur (BSJO) and Coimbatore (MH); Forest Research Institute, Dehra Dun (DD); Tropical Botanical Garden \& Research Institute, Trivandrum (TBGT); Herbarium, University College, Trivandrum (UCT) and Herbarium, Department of Botany, Kariyavattom ('KVM'). Mr. Sathish Kumar of TBGT was generous to send us the pickled specimens of some of his Oberonia collections. We are indebted to them all for the help rendered. We are also thankful to Mr. K. Sivanandan, Senior Artist, Botanical Survey of India, Coimbatore for carefully transferring our pencil drawings to Indian ink plates making them suitable for publication, and to Mr. N.G.R. Nair for his stoical typing.

\section{REFERENCES}

ABRahaM, A. \& P. VATSALA. 1981. Introduction to Orchids with Illustrations and Descriptions of 150 South Indian Orchids. India.

ANSARI, R., NAIR, N.C. \& V.J. NAIR. 1982. An analysis of the lip of Oberonias in Andhra Pradesh, Kerala and Tamil Nadu. J. Econ. Tax. Bot. 3: 113-119.

BANERJEE, M.L. 1982. Orchids of Nepal, ed. 2. Dehra Dun.

BLATTER, E. \& C. MCCANN. 1931. Orchidaceae, in: Blatter, Revision of the Flora of Bombay Presidency. J. Bombay Nat. Hist. Soc. 35.

DUTHIE, J.F. 1906. The Orchids of the North-Western Himalaya. Ann. Roy. Bot. Gard. Calcutta, 9, 2.

HoLTTUM, R.E. 1957. Orchids of Malaya. A revised Flora of Malaya 1, ed. 2. Singapore.

HOOKER, J.D. 1888. The Flora of British India 5: 675-686. London.

JAIN, S.K. \& A. MEHROTRA. 1984. A Preliminary Inventory of Orchidaceae in India. Howrah.

JAYAWEERA, D.M.A. 1981. Orchidaceae, in: Dassanayake, M.D. \& F.R. Fosberg: A revised Handbook to the Flora of Ceylon, vol. 2. New Delhi.

JOSEPH, J. 1982. Orchids of Nilgiris. Rec. Bot. Surv. India 22: 1-144. 
KATAKI, S.K. 1986. Orchids of Meghalaya. Shillong.

- ,JAIN, S.K. \& A.R.K. SASTRY. 1984. Threatened and Endemic Orchids of Sikkim and North-Eastern India. Calcutta.

KING, G. \& R. PANTLING. 1895. On some new Orchids from Sikkim. J. As. Soc. Bengal II, 64, 3.

- \& - 1897. Some new Indo-Malayan Orchids. J. As. Soc. Bengal II, 66, 3.

— \& - 1898. The Orchids of Sikkim Himalaya. Ann. Roy. Bot. Gard. Calcutta 8: 1-342.

LINDLEY, J. 1830. The Genera and Species of Orchidaceous Plants. London.

- 1859. Folia Orchidaceae. Oberonia. London.

PRADHAN, U.C. 1979. Indian Orchids: Guide to Identification \& Culture, vol. 2. Kalimpong.

RAO, A.S. 1979. Orchids of India. New Delhi.

SANTAPAU, H. \& Z. KAPADIA. 1966. The Orchids of Bombay. India.

SCHLECHTER, R. 1911. Die Orchidaceen von Deutsch Neu Guinea. Feddes Repert. Beih. 1: 1-1079.

SemENFAdEN, G. 1968. The genus Oberonia in Mainland Asia. Dansk Bot. Ark. 25 (3): 1-125.

- 1978. Orchid genera in Thailand VII: Oberonia Lindley. Dansk Bot. Ark. 33 (1): 7-41.

WIGHT, R. 1851. Icones Plantarum Indiae Orientalis, Vol. 5 (1): Orchideae. Pl. 1622-1630. New York.

\section{SYSTEMATIC TREATMENT}

\section{Oberonia Lindley}

Oberonia Lindley, Gen. \& Sp. Orch. (1830) 15 (nom. cons.). - T y p e: Oberonia iridifolia Lindley (Typ. cons.).

Iridorkis Thou., Nouv. Bull. Sci. Soc. Philom. Paris 1 (1809) 319. - T y p e: Non designatus.

Erect or pendulous epiphytes, with or without a prominent stem. Leaves distichous, laterally compressed, terete or ovate in cross section, fleshy, with or without an articulation near the base. Inflorescence a terminal spike which may be sessile or borne on a terete or flattened scape. Flowers bracteate, minute, up to $5.25 \mathrm{~mm}$ long and $2 \mathrm{~mm}$ across, pedicelled or sessile or sunk into pits on the spike. Bracts shorter or longer than the ovary and pedicel. Sepals and petals similar or dissimilar, gland-dotted or not. Sepals equal or subequal among themselves, antrorse or spreading or reflexed in flower. Petals spreading or reflexed or circinnate. Lip antrorse or reflexed, gland-dotted or not, 2-3-lobed or entire, without or with a saccate or tubular or cushion-like disc at the proximal end; lateral lobes of lip entire or variously dissected, spreading or erect or bend round the column; midlobe entire or 2-lobuled or deeply cut into many laciniae. Column minute, cylindric or globose or disciform, winged or not; clinandrium apical or dorsal, often surrounded by a wing, with or without the rostellum forming a protuberance at the distal end; operculum concave, of varying shapes; stigma of varying shapes. Pollinia 4, waxy, yellow, in pairs, without caudicles. Capsules longitudinally ridged.

D i s $\mathrm{tr}$ i b u tio n. From South Africa to Samoa through India, China, Burma, Thailand, Malesia, etc.

KEY TO THE SECTIONS OF OBERONIA

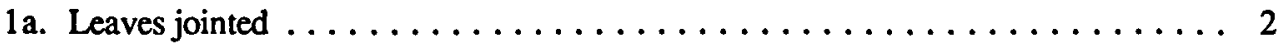

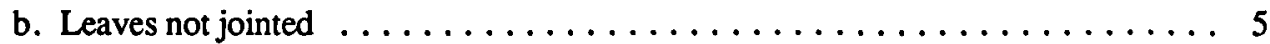

2a. Leaves terete or ovate-oblong in cross section ........ Section I (species 1-2)

b. Leaves laterally compressed, flattened lenticular in cross section $\ldots \ldots \ldots \ldots$ 
3a. Scape flattened or two-winged laterally . . . . . . . . . . . . . 4

b. Scape terete, not winged, often insignificant ...... Section IV (species 16-27)

4a. Flowers arranged in verticils on the rachis; lip distinctly two- or three-lobed; lateral sepals reflexed .................... Section III (species 4-15)

b. Flowers arranged spirally on the rachis; lip not lobed; lateral sepals antrorse.

Section II (species 3)

5a. Lip with the lateral lobes raised vertically above the column like two horns.

Section V (species 28)

b. Lip not lobed, or when lobed the lateral lobes are not raised vertically above the column ....................... Section VI (species 29-41)

\section{SECTION I}

\section{KEY TO THE SPECIES OF SECTION I}

1a. Leaves longer than the spike; dorsal sepal erect and lateral sepals antrorse; petals linear-oblong; midlobe of lip oblong, 6-laciniate; clinandrium dorsal.

1. O. myosurus Lindley

b. Leaves shorter than the spike; sepals reflexed; petals ovate; midlobe of lip suborbicular, 2-lobuled; clinandrium apical ........ 2. O. sulcata Joseph \& Chowdhury

\section{Oberonia myosurus Lindley - Fig. 1.}

Oberonia myosurus Lindley, Gen. \& Sp. Orch. (1830) 16, p.p. (excl. syn.); Fol. Orch. Oberon. (1859) 8; Hooker f., Fl. Brit. India 5 (1888) 685; Seidenf., Dansk Bot. Ark 25 (3) (1968) 14; ibid. 33 (1) (1978) 10; Arora, Bull. Bot. Surv. India 14 (1975) 175; Pradhan, Indian Orch. 2 (1979) 204; Jain \& Mehrotra, Prel. Inv. Orch. India (1984) 97. - T y p e: Wallich 1947, Jaka, Nepal (K, holo).

Erect or pendulous epiphytes, acaulescent. Leaves articulate at the base, up to $12 \mathrm{~cm}$ long, $0.8 \mathrm{~cm}$ thick, linear, terete, fleshy, much pointed at apex. Scape up to $2 \mathrm{~cm}$ long, terete. Spike up to $3.5 \mathrm{~cm}$ long. Flowers subsessile, $2.25 \mathrm{~mm}$ long, $1.5 \mathrm{~mm}$ across, yellowish green, closely scattered giving the spike a fleshy appearance. Bracts longer than the ovary, 2 by $0.5 \mathrm{~mm}$, lanceolate, acuminate, irregularly dentate along margins. Sepals \& petals dissimilar, sparsely gland-dotted; sepals dissimilar, entire; dorsal sepal erect in flower, 1 by $0.5 \mathrm{~mm}$, ovate-oblong, obtuse, entire; lateral sepals antrorse in flower, 1.25 by $0.5 \mathrm{~mm}$, ovate-lanceolate, subacuminate, entire, minutely keeled at the back; petals spreading in flower, 1 by $0.25 \mathrm{~mm}$, linear-oblong, obtuse, subentire. Lip antrorse, oblong in outline, 3-lobed, $1.75 \mathrm{~mm}$ long, $0.75 \mathrm{~mm}$ across both lateral lobes and midlobe, gland-dotted; lateral lobes oblong-cuneate, ear-like and spreading in flower, deeply dissected; midlobe oblong, deeply cut into 6 laciniae; disc indistinct. Ovary \& pedicel $0.75 \mathrm{~mm}$ long. Column $0.42 \mathrm{~mm}$ long, $0.35 \mathrm{~mm}$ thick, cylindric; clinandrium dorsal, suborbicular, winged ventrally; operculum $0.33 \mathrm{~mm}$ long, $0.3 \mathrm{~mm}$ broad, ovate, triangular and acute at apex; 
rostellum shorter than the clinandrial wing, minute, triangular, acute; stigma obovate; pollinia 0.17 by $0.14 \mathrm{~mm}$, obovoid.

E c o lo g y. Flowering July onwards. Altitude $1500-2000 \mathrm{~m}$.

Di s tri bution. India (Uttar Pradesh), Burma, China, Nepal.

Specimens examined:

INDIA. Uttar Pradesh: Kumaon, Arora 41332 (BSD).

\section{Oberonia sulcata Joseph \& Chowdhury - Fig. 2.}

Oberonia sulcata Joseph \& Chowdhury, J. Bombay Nat. Hist. Soc. 63 (1966) 54; Pradhan, Indian Orch. 2 (1979) 699; Jain \& Mehrotra, Prel. Inv. Orch. India (1984) 99. - T y p e: Joseph 40358, Selari forest, NEFA, $2230 \mathrm{~m}$ (CAL, holo; ASSAM).

Erect epiphytes, acaulescent. Leaves articulate at base, up to $12 \mathrm{~cm}$ long, $0.5 \mathrm{~cm}$ thick, linear, terete or ovate-oblong in cross section, fleshy, pointed towards apex. Scape up to $2.5 \mathrm{~cm}$ long, terete. Spike up to $15 \mathrm{~cm}$ long. Flowers pedicelled, $2.75 \mathrm{~mm}$ long, $2 \mathrm{~mm}$ across, yellowish brown, in verticils $2-4 \mathrm{~mm}$ apart. Bracts longer than the ovary and pedicel, up to 5 by $1 \mathrm{~mm}$, basal ones the longest, ovate-lanceolate, acuminate, lacerate along margins. Sepals \& petals dissimilar, glabrous; sepals subsimilar, 1.25 by $1 \mathrm{~mm}$, entire, reflexed; dorsal sepal ovate, obtuse, lateral sepals obliquely ovate, subacute; petals spreading in flower, 1.5 by $1 \mathrm{~mm}$, ovate, obtuse, irregularly toothed along margins. Lip antrorse, ovate or quadrangular in outline, 3-lobed, $1.75 \mathrm{~mm}$ long, $1.5 \mathrm{~mm}$ across lateral lobes and $1.25 \mathrm{~mm}$ across midlobe; lateral lobes oblong, wing-like on spreading, bend inwards in flower but not interlocking by their tips, toothed along margins; midlobe suborbicular, 2-lobuled; lobules oblong, obtuse at apex, subentire along margins, diverging; sinus shallow; disc indistinct. Ovary \& pedicel $1.5 \mathrm{~mm}$ long. Column $0.45 \mathrm{~mm}$ long, 0.51 mm thick, cylindric; clinandrium apical, orbicular, winged around, saccate; operculum 0.24 $\mathrm{mm}$ long, $0.42 \mathrm{~mm}$ broad, laterally elongated oblong, obtuse at apex; rostellum triangular, obtuse, equalling the clinandrial wing; stigma crescent-shaped; pollinia 0.21 by $0.17 \mathrm{~mm}$, obovoid.

E c o lo g y. Flowering August onwards. Altitude $2000-2700 \mathrm{~m}$.

Dis tri bution. India (Arunachal Pradesh). Endemic to Eastern Himalayas.

N o t e. Joseph \& Chowdhury (1.c.) while establishing the species Oberonia sulcata compared it with the Malayan plant, $O$. rosea Hooker $f$. On critical examination of the type specimen, it was found that the leaves are not laterally compressed as in $O$. rosea, but are almost oval in cross section as in the Vietnamese species $O$. langbianensis Gagnep. (in Bull. Soc. Bot. Fr. 79, 1932, 168). The other features like reflexed sepals, ovate and erose petals, the shape of the lip, etc. of $O$. sulcata also agree with the description and illustrations of the latter as provided by Seidenfaden (1978). However, since we could not examine any specimen of $O$. langbianensis, we retain the name $O$. sulcata Joseph \& Chowdhury for the Indian specimen.

S pecimens examined:

INDIA. Arunachal Pradesh: Kameng, Selari Forest, Joseph 40358 (CAL, type). 
3. Oberonia pachyrachis Rchb. f. ex Hooker f. - Fig. 3.

Oberonia pachyrachis Rchb. f. ex Hooker f., F1. Brit. India 5 (1888) 681; King \& Pantling, Ann. Roy. Bot. Gard. Calcutta 8 (1898) 4, Pl. 3; Seidenf., Dansk Bot. Ark. 25 (3) (1968) 19; ibid. 33 (1) (1978) 11; Pradhan, Indian Orch. 2 (1979) 193; Jain \& Mehrotra, Prel. Inv. Orch. India (1984) 97. - T y p e: Falconer s.n., Garhwal (K, holo).

Mostly pendulous epiphytes, acaulescent. Leaves articulate at the base, up to 13 by 1.5 $\mathrm{cm}$, oblong-ensiform, acute or subacuminate. Scape flattened, up to 9 by $1.5 \mathrm{~cm}$, adnate to the uppermost leaf. Spike up to $12 \mathrm{~cm}$ long, $1 \mathrm{~cm}$ across, terete, fleshy. Flowers sessile, $1.25 \mathrm{~mm}$ long, $1.25 \mathrm{~mm}$ across, greenish yellow to orange brown, sunken into pits on the fleshy spike, spirally arranged. Bracts slightly exceeding the ovary, 0.5 by $0.5 \mathrm{~mm}$, ovate-orbicular, obtuse, lacerate along margins. Sepals \& petals dissimilar, sparsely glanddotted; sepals dissimilar; dorsal sepal 0.5 by $0.5 \mathrm{~mm}$, ovate, obtuse, subentire along margins, reflexed in flower; lateral sepals 0.75 by $0.5 \mathrm{~mm}$, oblong, acute, entire along margins, antrorse; petals 0.5 by $0.25 \mathrm{~mm}$, linear-oblong, obtuse, entire, spreading in flower. Lip antrorse, ovate-orbicular, obtuse, not lobed, $0.75 \mathrm{~mm}$ long, $0.75 \mathrm{~mm}$ broad, glanddotted, subentire and induplicate, base bend upwards like two auricles laterally to the column; disc suborbicular, thick and cushion-like towards the distal end. Ovary $0.25 \mathrm{~mm}$ long. Column $0.3 \mathrm{~mm}$ long and thick, subglobose; clinandrium dorsal, orbicular, surrounded by spreading wings; operculum $0.18 \mathrm{~mm}$ long, $0.42 \mathrm{~mm}$ broad, laterally elongated oblong, acute at apex; rostellum like a minute triangular protuberance, acute, shorter than the clinandrial wing; stigma minute, saccate; pollinia 0.21 by $0.12 \mathrm{~mm}$, obovoid.

E c o lo g y. Flowering September-March. Altitude 1000-1800 m.

Dis tributi on. India (Meghalaya, Nagaland, Sikkim, Uttar Pradesh), Bhutan, Burma, China, Nepal, Taiwan.

Specimens examined:

INDIA. Meghalaya: Jaintea hills, Pantling s.n. (CAL, acc. no. nil). K. \& J. Hills, Kanjilal 8871 (ASSAM). Nongpoh, Collector? 23005 (DD). Nagaland, Kohima, Hynniewta 56062 (ASSAM). Zubsa, Hynniewta 80059 (ASSAM). Sikkim: Teesta, Pantling 105 (Cal). Uttar Pradesh: Dehra Dun, Gamble s.n. (CAL, acc. no. 449674). Garhwal, Nair 35916 (BSD). Pithoragarh, Arora 55805 (BSD).

\section{SECTION III}

KEY TO THE SPECIES OF SECTION III

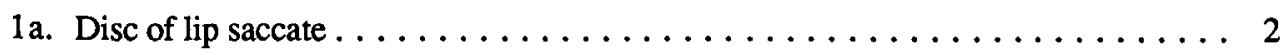

b. Disc of lip not saccate but cushion-like or indistinct $\ldots \ldots \ldots \ldots \ldots \ldots 7$

2a. Lateral lobes of lip laterally elongated; disc crescent-shaped.

4. O. sebastiana Shetty \& Vivek.

b. Lateral lobes of lip longitudinally elongated; disc ovate or bisaccate ........ 3

3a. Lip papillose .............. 5. O. chandrasekharanii Nair et al.

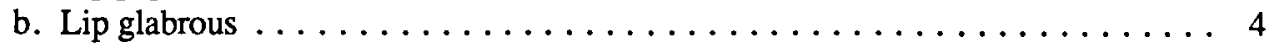


4a. Disc 2-lobed; midlobe of lip with a distinct rounded protuberance between the lobules $\ldots \ldots \ldots \ldots \ldots \ldots \ldots \ldots \ldots \ldots$. $0 . \ldots \ldots$ platycaulon Wight

b. Disc not 2-lobed; midlobe of lip without any protuberance between the lobules . . 5

5a. Clinandrium apical, uniformly winged around and bowl-like; rostellum not developed ............... 7. O. seidenfadeniana Joseph \& Vajravelu

b. Clinandrium dorsal, not uniformly winged around or bowl-like; rostellum oblong or

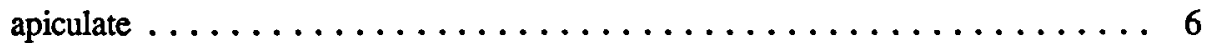

6a. Lateral lobes of lip folded upwards and encircling the column in flower; stigma orbicular; rostellum oblong . . . . . . . . . 8. 0. josephii Saldanha

b. Lateral lobes of lip spreading in flower, stigma rectangular, rostellum apiculate.

9. O. brunoniana Wight

7a. Lateral lobes of lip bend upwards and interlocking at their tips above the column; column more than $1 \mathrm{~mm}$ long; inflorescence with a definite sterile apex.

10. O. balakrishnanii Ansari

b. Lateral lobes of lip not interlocking at their tips above the column; column less than $1 \mathrm{~mm}$ long; inflorescence without any definite sterile apex . . . . . . . 8

8a. Petals ovate; lip deeply dentate along margins ..... 15. O. denticulata Wight

b. Petals linear or oblanceolate; lip entire or shallowly crenate along margins . . . . 9

9a. Lip ovate or semiorbicular in outline, shallowly crenate along margins, 3-lobed with two lateral lobes and a 2 -lobuled midlobe . . . . . . . . . . . . . . . 10

b. Lip quadrate in outline, entire along margins, without any lateral lobes but 2-lobed at apex ..................... 14. O. zeylanica Hooker f.

10a. Lip reflexed in flower; clinandrium oblong, saccate; flowers more than $5 \mathrm{~mm}$ long. 13. O. anamalayana Joseph

b. Lip antrorse in flower; clinandrium suborbicular, not saccate; flowers not more than

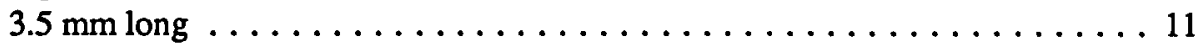

11a. Lateral lobes of lip ear-like; lobules of midlobe orbicular, diverging; disc not distinct; petals oblanceolate; bracts entire or shallowly serrate.

11. O. nayarii Ansari \& Balak.

b. Lateral lobes of lip not ear-like; lobules of midlobe oblong, converging; disc with a crescent-shaped, cushion-like band at the distal end; petals linear; bracts irregularly denticulate ................... 12. O. santapaui Kapadia

\section{Oberonia sebastiana Shetty \& Vivek. - Fig. 4.}

Oberonia sebastiana Shetty \& Vivek., Bull. Bot. Survey India 17 (1975/1978) 157; Ansari et al., J. Econ. Tax. Bot. 3 (1982) 117; Jain \& Mehrotra, Prel. Inv. Orch. India (1984) 99. - T y p e: Shetty \& Vivekananthan 26480, Umaiyamalai, Anai mudi slopes, Kerala, 2075 m, 17.11.1965 (CAL, holo; MH). 
Pendulous, caespitose epiphytes, acaulescent. Leaves articulate at base, up to 20 by 1.2 $\mathrm{cm}$, ensiform, acute or subacuminate. Scape up to $10 \mathrm{~cm}$ long, flattened and adnate to the reduced uppermost leaf. Spike up to $30 \mathrm{~cm}$ long, pendulous. Flowers pedicelled, $2.5 \mathrm{~mm}$ long, $1 \mathrm{~mm}$ across, yellow, subverticillate. Bracts longer than the ovary and pedicel, 1.75 by $1 \mathrm{~mm}$, ovate, subacuminate, irregularly denticulate along margins, glabrous, sparsely gland-dotted. Sepals \& petals dissimilar, glabrous, reflexed; sepals dissimilar; dorsal sepal 1 by $0.5 \mathrm{~mm}$, oblong, obtuse, entire; lateral sepals 1 by $0.75 \mathrm{~mm}$, ovate, subacute, induplicate; petals 1 by $0.25 \mathrm{~mm}$, oblong, obtuse, subentire. Lip antrorse, semiorbicular in outline, 3-lobed, $1.25 \mathrm{~mm}$ long, $2.25 \mathrm{~mm}$ across lateral lobes and 0.75 across midlobe, glanddotted, glabrous; lateral lobes oblong-obovate or cuneate, wing-like, subentire, ascending or sometimes encircling the column in flower; midlobe cuneate, 2-lobuled; lobules obovatecuneate, subentire, diverging; disc crescent-shaped, saccate. Ovary \& pedicel $1.5 \mathrm{~mm}$ long. Column $0.36 \mathrm{~mm}$ long, $0.45 \mathrm{~mm}$ across, obovoid; clinandrium apical, orbicular, winged around giving a bowl-like appearance; operculum $0.26 \mathrm{~mm}$ long, $0.38 \mathrm{~mm}$ broad, laterally elongated oblong, rounded at apex; rostellum rounded with an apiculum, slightly shorter than the clinandrial wing; stigma orbicular, saccate; pollinia 0.23 by $0.14 \mathrm{~mm}$, obovoid.

E c o log y. Flowering October-December. Altitude $1500-2500 \mathrm{~m}$.

D i s $\mathrm{t}$ i b u ti o n. India (Kerala, Tamil Nadu). Endemic to southern part of Western Ghats.

\section{Specimens examined:}

INDIA. Kerala: Idukki, Sebastine 17517 (MH); Shetty \& Vivekananthan 26480 (CAL, type; MH), 33404 (MH). Munnar, Rathakrishnan 16238 (MH). Tamil Nadu: Anamalai, Barber 4028 (MH); Chandrabose $57782(\mathrm{MH})$.

\section{Oberonia chandrasekharanii Nair et al. - Fig. 5.}

Oberonia chandrasekharanii Nair, Ramach. \& Ansari, Blumea 28 (1983) 361. - T y p e: Ramachandran 66948, Chandanathode, Cannanore Dist., Kerala, 825 m, 15.8.1980 (CAL, holo; MH).

Oberonia rangannaiana Murthy, Yoganaras. \& Nair, Curr. Sci. 56 (12) (1987) 621. - T y p e: Keshava Murthy \& party 4233, Bhagamandala to Mercara, $1200 \mathrm{~m}, 8$ Aug. 1983 (RRCBI).

Pendulous epiphytes, acaulescent. Leaves articulate at base, up to 15 by $1.5 \mathrm{~cm}$, ensiform, acute. Scape up to 9 by $0.6 \mathrm{~cm}$, flattened. Spikes up to $22 \mathrm{~cm}$ long, pendulous. Flowers pedicelled, $2 \mathrm{~mm}$ long, $1 \mathrm{~mm}$ across, pale greenish yellow, in verticils $2-3 \mathrm{~mm}$ apart. Bracts 2 by $1.25 \mathrm{~mm}$, ovate or lanceolate, acuminate, irregularly denticulate along margins, gland-dotted. Sepals \& petals reflexed, sparsely gland-dotted; sepals subsimilar; dorsal sepal 1.25 by $1 \mathrm{~mm}$, ovate-oblong, obtuse, entire; lateral sepals 1.25 by $1 \mathrm{~mm}$, ovateoblong, obtuse, induplicate; petals 1.25 by $0.5 \mathrm{~mm}$, linear, truncate and denticulate at apex, distantly denticulate along margins. Lip antrorse, semiorbicular or reniform in outline, 3-lobed, $1.5 \mathrm{~mm}$ long, $2 \mathrm{~mm}$ broad across lateral lobes, papillose, gland-dotted; lateral lobes cuneate and auriform, folded upwards round the column by the proximal end; midlobe $0.5 \mathrm{~mm}$ long, $0.75 \mathrm{~mm}$ broad, 2-lobuled with a broad sinus in between; lobules orbicular, disc ovate, concave and sac-like. Ovary \& pedicel $2 \mathrm{~mm}$ long. Column $0.39 \mathrm{~mm}$ long, $0.45 \mathrm{~mm}$ across, cylindric; clandrium apical, orbicular, winged around; operculum $0.3 \mathrm{~mm}$ long, $0.39 \mathrm{~mm}$ broad, suborbicular, rounded at apex; rostellum retuse, shorter than the clinandrial wings; stigma suborbicular, saccate; pollinia 0.3 by $0.18 \mathrm{~mm}$, obovoid.

E c o lo g y. Flowering August-November. Altitude $800-1500 \mathrm{~m}$. 
Dis tribution. India (Karnataka, Kerala, Tamil Nadu). Endemic to Western Ghats.

Not e. Murthy et al. (1.c.) while establishing their species $O$. rangannaiana compared it with $O$. brunoniana and considered it to be a distinct species. They might have missed to examine the specimens of $O$. chandrasekharanii which agree in all respects with the description of $O$. rangannaiana.

Specimens examined:

INDIA. Kerala: Cannanore, Ramachandran 66948 (CAL, type; MH), 54137 (MH). Idukki, Vivekananthan \& Raju 71135 (MH). Kottayam, Vivekananthan 21417 (MH). Palghat, Vajravelu 46154 (MH). Tamil Nadu: Coimbatore, Deb $31080(\mathrm{MH})$.

\section{Oberonia platycaulon Wight - Fig. 6 .}

Oberonia platycaulon Wight, Icon. 5 (1) (1851) 3, t. 1623; Lindley, Fol. Orch. Oberon. (1859) 2; Hooker f., Fl. Brit. India 5 (1888) 682; Santapau \& Kapadia, Orch. Bombay (1966) 70 (quoad nom.); Seidenf., Dansk Bot. Ark. 25 (3) (1968) 51; Pradhan, Indian Orch. 2 (1979) 201; Abraham \& Vatsala, Intr. Orch. (1981) 425; Ansari et al., J. Econ. Tax. Bot. 3 (1982) 115; Joseph, Orch. Nilgiris (1982) 85; Jain \& Mehrotra, Prel. Inv. Orch. India (1984) 98. - T y p e: Wight s.n., Pulney mountains (K ?).

Oberonia bisaccata Manilal \& Kumar, Kew Bull. 39 (1) (1984) 121. - T y p e: Sathish Kumar SV 10738, Silent Valley, near dam site, Kerala, 1982 (CALI, holo; K).

Caespitose epiphytes, mostly erect, acaulescent. Leaves articulate at base, up to 19 by $1.5 \mathrm{~cm}$, ensiform, acute. Scape up to 11 by $0.9 \mathrm{~cm}$, flattened and adnate to the uppermost leaf. Spike up to $9.5 \mathrm{~cm}$ long with or without a distinct sterile portion at apex, deflexed from base or decurved. Flowers pedicelled, $4 \mathrm{~mm}$ long, $1 \mathrm{~mm}$ across, pale or orange yellow, somewhat closely scattered on the rachis. Bracts equalling the ovary and pedicel, 2.25 by $1.25 \mathrm{~mm}$, ovate-lanceolate, acute, irregularly denticulate along margins, gland-dotted. Sepals \& petals dissimilar, sparsely gland-dotted, reflexed; sepals dissimilar, entire; dorsal sepal 1.5 by $0.75 \mathrm{~mm}$, oblong or ovate, obtuse; lateral sepals 1.5 by $1 \mathrm{~mm}$, ovate, acute; petals 1.5 by $0.25 \mathrm{~mm}$, linear, obtuse or truncate, entire. Lip antrorse, semiorbicular or ovate in outline, 3-lobed, $2 \mathrm{~mm}$ long, $2.75 \mathrm{~mm}$ across lateral lobes and $0.75 \mathrm{~mm}$ across midlobe, gland-dotted, glabrous; lateral lobes oblong-cuneate, ear-like, entire, encircling the column in flower; midlobe ovate or rectangular in outline, 2-lobuled with a distinct lobule-like protuberance at the sinus; lobules rounded; disc ovate, 2-saccate towards the proximal end. Ovary \& pedicel $2.25 \mathrm{~mm}$ long. Column $0.72 \mathrm{~mm}$ long and across, subglobose; clinandrium dorsal, quadrate, minutely winged around; operculum $0.48 \mathrm{~mm}$ long and broad, suborbicular or ovate, acute at apex; rostellum rounded with an apiculum, longer than the clinandrial wing; stigma suborbicular.

Ecolog y. Flowering August-November. Altitude above $1000 \mathrm{~m}$.

$\mathrm{D}$ is $\mathrm{t} \mathrm{r}$ i b u ti o $\mathrm{n}$. India (Kerala, Tamil Nadu). Endemic to the southern part of Western Ghats.

Notes. 1. Oberonia platycaulon is one of the lesser known species of the genus. Even though Hooker f. (l.c.) gave a wider distribution of the species from Concan to Nilgiris and Pulneys, there is no definite record of its availability in the northern part of Western Ghats (Santapau \& Kapadia, l.c.). The specimen which Santapau \& Kapadia used for their illustration possibly is $O$. seidenfadeniana.

2. Manilal \& Sathish Kumar (l.c.) while establishing their species $O$. bisaccata compared it with $O$. brunoniana and $O$. sebastiana and considered their species to differ from 
both in having 2 basal pouches on the lip, a 3-fid midlobe and a basally deflexed or recurved spike, bearing shortly pedicellate flowers. They overlooked $O$. platycaulon which is identical in all these respects.

Specimens examined:

INDIA. Kerala: Idukki, Vatsala s.n. ('KVM' acc. no. nil); Vivekananthan 48352 (MH). Palghat, Ansari 51492 (MH); Sathish Kumar SV 10738 (CALI, type of O. bisaccata).

7. Oberonia seidenfadeniana Joseph \& Vajravelu - Fig. 7.

Oberonia seidenfadeniana Joseph \& Vajravelu, Bull. Bot. Surv. India 13 (1971) 344; Pradhan, Indian Orch. 2 (1979) 696; Ansari et al., J. Econ. Tax. Bot. 3 (1982) 117; Jain \& Mehrotra, Prel. Inv. Orch. India (1984) 99. - T y p e: Joseph 17476, Andiparaishola, Anamalai hills, Tamil Nadu, 1350 m, 22 Sept. 1962 (CAL, holo; MH).

Erect or pendulous epiphytes, acaulescent. Leaves articulate at base, up to 10 by 1.3 $\mathrm{cm}$, ensiform, acute. Scape up to 10 by $0.8 \mathrm{~cm}$, flattened and adnate to the uppermost leaf. Spike up to $11 \mathrm{~cm}$ long, with a sterile tip $2-3 \mathrm{~cm}$ long, slightly arcuate. Flowers pedicelled, $2.5 \mathrm{~mm}$ long, $1.75 \mathrm{~mm}$ across, greenish or golden yellow, in close verticils. Bracts longer than the ovary and pedicel, 2 by $1.5 \mathrm{~mm}$, ovate-lanceolate, acuminate, irregularly denticulate along margins, gland-dotted. Sepals \& petals dissimilar, glabrous, reflexed; sepals dissimilar; dorsal sepal 1.25 by $0.75 \mathrm{~mm}$, oblong, obtuse and mucronate at apex, entire; lateral sepals 1.25 by $1 \mathrm{~mm}$, obliquely ovate, subacute, induplicate, minutely keeled on back at apex; petals 1.25 by $0.5 \mathrm{~mm}$, oblong, obtuse, subentire. Lip antrorse, semiorbicular in outline, 3 -lobed, $1.5 \mathrm{~mm}$ long, $2.25 \mathrm{~mm}$ across lateral lobes and $0.75 \mathrm{~mm}$ across midlobe, sparsely gland-dotted; glabrous; lateral lobes much broader than midlobe, oblong or obliquely cuneate, ear-like, subentire, encircling the column and interlocking at their tips in flower; midlobe quadrangular, minutely 2-lobuled; lobules separated by a very shallow sinus, slightly diverging or parallel; disc ovate, saccate towards the proximal end. Ovary \& pedicel $1.25 \mathrm{~mm}$ long. Column $0.36 \mathrm{~mm}$ long, cylindric; clinandrium apical, orbicular, widened and winged around giving a bowl-like appearance, $0.69 \mathrm{~mm}$ across; operculum $0.29 \mathrm{~mm}$ long, $0.5 \mathrm{~mm}$ broad, laterally elongated oblong-rectangular, truncate at apex; rostellum not developed; stigma rectangular.

E c o 1 o g y. Flowering March-September. Altitude 100-1500 m.

Dis tribution. India (Kerala, Tamil Nadu). Endemic to the southern part of Western Ghats.

Not e. The much laterally elongated structure of the lip as represented by Joseph \& Vajravelu (l.c.) is due to the rupturing of the disc. This is evident from the fact that they did not consider the presence of a saccate disc in their description.

Specimens examined:

INDIA. Tamil Nadu: Coimbatore, Joseph 17476 (CAL, type; MH).

8. Oberonia josephii Saldanha - Fig. 8.

Oberonia josephii Saldanha, Indian Forester 100 (1974) 568, fig. 2; Pradhan, Indian Orch. 2 (1979) 694; Jain \& Mehrotra, Prel. Inv. Orch. India (1984) 96. - T y p e: Saldanha 15247, near Genkalbetta, Hassan Dist., Karnataka, 900 m, 9 Oct. 1969 (JCB). 
Epiphytes, mostly erect, acaulescent. Leaves articulate at base, up to 28 by $1.6 \mathrm{~cm}$, ensiform, acute. Scape up to $18 \mathrm{~cm}$ long, flattened. Spike up to $25 \mathrm{~cm}$ long, with a definite sterile portion at the apex, arcuate or straight. Flowers pedicelled, $4.25 \mathrm{~mm}$ long, $1.5 \mathrm{~mm}$ across, white or orange, in distinct verticils. Bracts 2.5 by $1.5 \mathrm{~mm}$, lanceolate, subacute, irregularly denticulate along margins, gland-dotted. Sepals \& petals dissimilar, glabrous, reflexed; sepals subsimilar; dorsal sepal 2 by $1 \mathrm{~mm}$, oblong, obtuse, entire and induplicate; lateral sepals 2 by $1 \mathrm{~mm}$, oblong, subacute, minutely toothed along margins towards apex; petals 2 by $0.5 \mathrm{~mm}$, oblong-ovate, obtuse, minutely toothed along margins towards base. Lip antrorse, quadrate in outline, 3-lobed, $2.5-3.5 \mathrm{~mm}$ long, $2.5 \mathrm{~mm}$ across lateral lobes and 2.25-3.25 mm across midlobe, gland-dotted, glabrous; lateral lobes oblong, elongated and rounded at the proximal end, subentire, folded upwards and encircling the column; midlobe 2-lobuled; lobules orbicular, crenulate-serrate, diverging; sinus broad; disc ovate, saccate towards the proximal end. Ovary \& pedicel $2.25 \mathrm{~mm}$ long. Column 0.83 $\mathrm{mm}$ long, $0.68 \mathrm{~mm}$ thick, cylindric; clinandrium dorsal, orbicular, winged around with the wings somewhat spreading, not saccate; operculum $0.53 \mathrm{~mm}$ long, $0.57 \mathrm{~mm}$ broad, ovate, obtuse at apex; rostellum oblong, slightly projecting beyond the clinandrial wing; stigma orbicular, pollinia 0.48 by $0.23 \mathrm{~mm}$, clavate.

E c o lo g y. Flowering September-December. Altitude 900-1600 m.

Dis tribution. India (Karnataka). Endemic to Western Ghats.

Note. The petals are not always arching backwards and crossing each other as described by Saldanha (l.c.). The midlobe of the lip is generally broader than the one in $O$. brunoniana to which this species is allied, but the much smaller, falcate lateral lobes illustrated by Saldanha are merely a misinterpretation caused by not spreading them properly.

Specimens examined:

INDIA. Karnataka: Gopalaswamy hills, Naithani 23239 (MH); Yoganarasimhan 291 (MH); Himavat Gopal hills, Rao $18206(\mathrm{MH})$.

\section{Oberonia brunoniana Wight - Fig. 9.}

Oberonia brunoniana Wight, Icon. 5 (1) (1851) 3, t. 1622; Lindley, Fol. Orch. Oberon. (1859) 2; Hooker f., Fl. Brit. India 5 (1888) 681; Santapau \& Kapadia, Orch. Bombay (1966) 69 (quoad nom.); Seidenf., Dansk Bot. Ark. 25 (3) (1968) 50; Pradhan, Indian Orch. 2 (1979) 201; Abraham \& Vatsala, Intr. Orch. (1981) 422 (quoad nom.); Ansari et al., J. Econ. Tax. Bot. 3 (1982) 115; Joseph, Orch. Nilgiris (1982) 85. - T y p e: Wight s.n., Iyamally hills, Coimbatore (K ?).

Erect or pendulous epiphytes, acaulescent. Leaves articulate at base, up to 28 by $2 \mathrm{~cm}$, oblong-ensiform, narrowing from about the middle to an acute apex. Scape up to 16 by 0.8 $\mathrm{cm}$, flattened, adnate to the uppermost leaf. Spike up to $16 \mathrm{~cm}$ long, with a distinct and reflexed sterile tip $1.5-6 \mathrm{~cm}$ long, erect. Flowers pedicelled, $4 \mathrm{~mm}$ long, $2.75 \mathrm{~mm}$ across, pale greenish yellow to brick red, in verticils 2-3 mm apart. Bracts equalling or longer than the ovary and pedicel, 2 by $1.75 \mathrm{~mm}$, ovate, acute, irregularly denticulate along margins, gland-dotted. Sepals \& petals dissimilar, sparsely gland-dotted, glabrous, reflexed; sepals dissimilar in shape, 2 by $1.25 \mathrm{~mm}$, entire and induplicate; dorsal sepal oblong, obtuse; lateral sepals obliquely ovate, subacute; petals 2 by $0.75 \mathrm{~mm}$, lanceolate, obtuse or acute, subentire. Lip antrorse, ovate in outline, 3-lobed, $2.5 \mathrm{~mm}$ long, $2-2.75 \mathrm{~mm}$ across lateral lobes and $1.5 \mathrm{~mm}$ across midlobe, gland-dotted, glabrous; lateral lobes oblong or 
obliquely cuneate and ear-like, subentire, spreading in flower, not encircling the column; midlobe 2-lobuled; lobules oblong with rounded or truncate apex, diverging; sinus broad; disc ovate, saccate towards the proximal end. Ovary \& pedicel $1.5 \mathrm{~mm}$ long. Column $0.8 \mathrm{~mm}$ long, $0.75 \mathrm{~mm}$ thick, subglobose; clinandrium dorsal, orbicular, minutely winged around, not saccate; operculum $0.4 \mathrm{~mm}$ long, $0.6 \mathrm{~mm}$ broad, laterally elongated oblong or suborbicular, truncate at apex; rostellum apiculate, not projecting beyond the clinandrial wing; stigma rectangular; pollinia 0.45 by $0.2 \mathrm{~mm}$, clavate.

Ec o lo g y. Flowering July-October. Altitude $800-2200 \mathrm{~m}$.

Distribution. India (Kerala, Tamil Nadu). Endemic to the southern part of Western Ghats.

N o te s. 1. As stated by Seidenfaden (1.c.) the specimens of Oberonia brunoniana, $O$. platycaulon and $O$. santapaui are found mixed up in the herbaria. This might have happened due to the close resemblance of these species and also to the collection of a number of variants which subsequently were raised to species like $O$. anamalayana, $O$. josephii, $O$. seidenfadeniana, etc. This probably might have led Abraham \& Vatsala (l.c.) to describe their $O$. santapaui specimens wrongly under the name $O$. brunoniana. The characters used by Wight (1851) for describing his two species $(O$. brunoniana and $O$. lindleyana) were adequate enough to segregate these forms at that period. Thus, the lanceolate petals and entire (subentire) lip which he recognised in $O$. brunoniana are constant and contrasting with those structures in $O$. lindleyana. Joseph (l.c.) felt that these two species exhibit hardly any difference in floral structure, although they are distinct vegetatively. But on detailed observations, collective floral as well as vegetative structural differences as shown in the key are noted among these allied species. The width of lip and inflorescence which Seidenfaden (l.c.) considered for separating these two species is not practicable (Ansari et al., 1.c.).

2. The Ceylon specimen Thwaites 3869 which Seidenfaden (l.c.) with doubt cited under $O$. brunoniana is $O$. zeylanica (vide Jayaweera, 1981).

Specimens examined:

INDIA. Kerala: Agastyamalai, Joseph 44615 (MH). Chemungi, Mohanan 61749 \& 62820 (MH). Ponmudi, Nair 43896 (MH). Tamil Nadu: Coimbatore, Chandrabose 57254 (MH). Madurai, Subramanyam 9514 (MH). Nilgiris, Collector? s.n. (MH, acc. no. 50133 to 50138); Ellis 43350 (MH).

\section{Oberonia balakrishnanii Ansari, spec. nov. - Fig. 10.}

Oberonia balakrishnanii Ansari, spec. nov. Oberonia josephii affinis sed scapo longiore, bracteis ovatis, lobo medio breviore, lobis lateralibus auriculatis, columna longa et clavata, rostello triangulare acuminato et disco indistincto differt.

Epiphytes, mostly erect, acaulescent. Leaves articulate at base, up to 12 by $1.8 \mathrm{~cm}$, oblong-ensiform, acute or subacuminate. Scape up to $14 \mathrm{~cm}$ long, flattened, adnate to the reduced uppermost leaf. Spike up to $9 \mathrm{~cm}$ long, arcuate, with a distinct sterile tip 1-2 cm long. Flowers pedicelled, $4 \mathrm{~mm}$ long, $2 \mathrm{~mm}$ across, in verticils $2 \mathrm{~mm}$ apart. Bracts equalling the ovary and pedicel, 2 by $1.5 \mathrm{~mm}$, ovate, subacuminate, lacerate along margins, gland-dotted. Sepals \& petals dissimilar, sparsely gland-dotted, glabrous, reflexed; sepals subsimilar, 2 by $1 \mathrm{~mm}$; dorsal sepal oblong, obtuse, entire; lateral sepals oblong, obtuse, entire, minutely keeled on back at apex; petals 2 by $0.5 \mathrm{~mm}$, oblong, rounded at apex, crenate along margins. Lip antrorse, semiorbicular in outline, 3-lobed, $2.5 \mathrm{~mm}$ long, $3.5 \mathrm{~mm}$ 
across lateral lobes and $2 \mathrm{~mm}$ across midlobe, gland-dotted; lateral lobes obliquely cuneate, ear-like, subentire, bend upwards round the column and interlocking by their ends; midlobe 2-lobuled; lobules orbicular, crenate or subentire, diverging; sinus broad; disc indistinct. Ovary \& pedicel $2 \mathrm{~mm}$ long. Column $1.1 \mathrm{~mm}$ long, $0.6 \mathrm{~mm}$ thick, clavate; clinandrium dorsal, orbicular, winged around, saccate; operculum $0.53 \mathrm{~mm}$ long, $0.45 \mathrm{~mm}$ broad, ovate, obtuse at apex; rostellum triangular, acuminate, projecting above the clinandrial wing; stigma suborbicular, pollinia 0.45 by $0.15 \mathrm{~mm}$, clavate.

Ecolog y. Flowering October.

$\mathrm{D}$ is $\mathrm{tr}$ i b u ti o $\mathrm{n}$. India (Tamil Nadu). Known only from the type locality.

Notes. 1. Oberonia balakrishnanii is allied to $O$. josephii but differs by the longer scape, ovate bracts, smaller midlobe, ear-like lateral lobes, long and clavate column, triangular, acuminate rostellum and in the absence of a distinct disc.

2. This species is named after Dr. N.P. Balakrishnan, Scientist SE, Botanical Survey of India, Coimbatore as a humble token of the first author's indebtedness to him for the continuous encouragement and valuable suggestions received throughout the research activities.

Specimens examined:

INDIA. Tamil Nadu: Pulneys, Church Cliff, Brown 1837 (MH, Holotype).

\section{Oberonia nayarii Ansari \& Balak., spec. nov. - Fig. 11.}

Oberonia nayarii Ansari \& Balak., spec. nov., ex affinitate $O$. santapaui et $O$.forcipata, ab uterque bracteis subserratis vel integris, petalis oblanceolatis vel oblongis, labio lobis lateralibus auriculato, disco indistincto et rostello obtuso distinctus.

Mostly erect epiphytes, acaulescent. Leaves articulate at base, up to 5.5 by $0.9 \mathrm{~cm}$, oblong-ensiform, subacute, dirty green. Scape up to $3 \mathrm{~cm}$ long, minutely 2 -winged. Spike up to $7 \mathrm{~cm}$ long and $0.5 \mathrm{~cm}$ thick, erect. Flowers pedicelled, white or pale greenish yellow turning to brownish yellow, in verticils $1.25-2.75 \mathrm{~mm}$ apart. Bracts 1 by $0.75 \mathrm{~mm}$, ovate, acute, entire or shallowly serrate, sparsely gland-dotted. Sepals \& petals dissimilar, reflexed; sepals dissimilar, 1 by $0.75 \mathrm{~mm}$; dorsal sepal oblong, obtuse, entire; lateral sepals ovate, acute, entire and induplicate along margins, minutely keeled on back at apex; petals 1.25 by $0.25 \mathrm{~mm}$, oblanceolate, acute, entire or subserrate along margins. Lip antrorse, semiorbicular or ovate in outline, 3-lobed, 1-1.5 mm long, 1-2 mm across lateral lobes and $0.75 \mathrm{~mm}$ across midlobe, gland-dotted, glabrous; lateral lobes oblong-cuneate and earlike, shallowly crenate, spreading in flower, not encircling the column; midlobe 2-lobuled; lobules orbicular, shallowly crenate, diverging; sinus broad, generally with a round protuberance; disc ovate, indistinct. Ovary \& pedicel $1.25 \mathrm{~mm}$ long. Column $0.6 \mathrm{~mm}$ long, 0.53 $\mathrm{mm}$ thick, cylindric-globose; clinandrium dorsal, suborbicular, minutely winged around, not saccate; operculum $0.36 \mathrm{~mm}$ long, $0.48 \mathrm{~mm}$ broad, laterally elongated oblong, obtuse at apex; rostellum semiorbicular, obtuse at apex, shorter than clinandrial wing; stigma rectangular; pollinia 0.41 by $0.18 \mathrm{~mm}$, clavate.

E c o lo g y. Flowering December-July. Altitude 800-1800 m.

$\mathrm{D}$ i s $\mathrm{t}$ r i b u t i o n. India (Karnataka, Kerala, Tamil Nadu). Endemic to Western Ghats.

$\mathrm{N}$ ot es. 1 . Oberonia nayarii is allied to $O$. santapaui and to the Sri Lankan species 0 . forcipata Lindley but differs in the entire or subserrate bracts, oblanceolate or oblong petals, ear-like lateral lobes of the lip, obtuse rostellum and indistinct disc. 
2. The specific name is given to honour Dr. M.P. Nayar, Director of the Botanical Survey of India, in appreciation of his valuable contributions to the taxonomy of Indian plants.

Specimens examined:

INDIA. Tamil Nadu: Nilgiris, Pykara, C.A. Barber 2687 (MH, Holotype). Karnataka: Chikmangalur, R.S. Raghavan 85373 (BSI). Mysore, B.D. Naithani 23237 (MH); A.V.N. Rao 18205 (MH). Kerala: Trivandrum, M. Mohanan 52522 \& 66057 (MH). Tamil Nadu: Kanniyakumari, A.N. Henry 52425 (MH) (all paratypes).

12. Oberonia santapaui Kapadia - Fig. 12.

Oberonia santapaui Kapadia, J. Bombay Nat. Hist. Soc. 57 (1960) 265; Santapau \& Kapadia, Orch. Bombay (1966) 72; Seidenf., Dansk Bot. Ark. 25 (3) (1968) 50; Pradhan, Indian Orch. 2 (1979) 696; Abraham \& Vatsala, Intr. Orch. (1981) 429; Ansari et al., J. Econ. Tax. Bot. 3 (1982) 116; Joseph, Orch. Nilgiris (1982) 87; Jain \& Mehrotra, Prel. Inv. Orch. India (1984) 99. - Oberonia lindleyana Wight, Icon. 5 (1) (1851) 3, t. 1624 (non Brongn. ex Duperr. 1834); Lindley, Fol. Orch. Oberon. (1859) 2; Hooker f., Fl. Brit. India 5 (1888) 681. - T y p e: Wight s.n., Iyamally hills, Coimbatore (K ?).

Erect or pendulous epiphytes, acaulescent. Leaves articulate at base up to 17 by $2.5 \mathrm{~cm}$, oblong, obtuse or acute, dirty brown. Scape up to 8 by $0.8 \mathrm{~cm}$, flattened. Spike up to 19 $\mathrm{cm}$ long and $0.5 \mathrm{~cm}$ thick, fleshy, mostly decurved. Flowers pedicelled, $3 \mathrm{~mm}$ long, 1.5 $\mathrm{mm}$ across, reddish brown or straw-coloured, in verticils 1.5-2 mm apart. Bracts longer than the ovary and pedicel, 2.25 by $1 \mathrm{~mm}$, lanceolate, acute, irregularly denticulate along margins, gland-dotted. Sepals \& petals dissimilar, gland-dotted, reflexed; sepals subsimilar, 1.25 by $0.75 \mathrm{~mm}$, entire; dorsal sepal oblong, obtuse; lateral sepals oblong-ovate, obtuse or subacute; petals 1.25 by $0.25 \mathrm{~mm}$, linear, truncate or obtuse, reflexed and circinnate in flower. Lip antrorse, ovate in outline, 3-lobed, $2.25 \mathrm{~mm}$ long, $2.25 \mathrm{~mm}$ across lateral lobes and $1.5 \mathrm{~mm}$ across midlobe, densely gland-dotted, glabrous; lateral lobes narrow and longitudinally elongated oblong around the disc, shallowly crenate, spreading or recurved along margins in flower, not encircling the column; midlobe 2-lobuled; lobules oblong, shallowly crenate, rounded at apex, converging but not overlapping; sinus broad with a conical or rounded protuberance; disc ovate with a crescent-shaped cushion-like band at the distal end. Ovary \& pedicel $1.5 \mathrm{~mm}$ long. Column $0.75 \mathrm{~mm}$ long, $0.6 \mathrm{~mm}$ thick, cylindric; clinandrium dorsal, suborbicular, minutely winged around, not saccate; operculum $0.36 \mathrm{~mm}$ long, $0.3 \mathrm{~mm}$ broad, vertically elongated ovate, obtuse at apex; rostellum triangular, acute, equalling or slightly projecting above the clinandrial wing; stigma suborbicular, pollinia 0.38 by $0.15 \mathrm{~mm}$, clavate.

Ec olo g y. Flowering October-January. Altitude 600-1700 m.

D i s $\mathrm{r}$ i b u t i o n. India (Karnataka, Kerala, Maharashtra, Tamil Nadu). Endemic to Western Ghats.

Specimens examined:

INDIA. Karnataka: Hassan, Saldanha 15941 (MH). Mysore, Rao 18210 (MH). Kerala: Calicut, Sultan Batteri, Ellis 18564 (MH). Cannanore, Chandanathode, Ramachandran 54138 (MH). Kottayam, Sebastine 18475 (MH); Palghat, Bhargavan 56901 (MH). Trichur, Sebastine 15033 (MH). Tamil Nadu: Coimbatore, Joseph 13074 (MH). Kanniyakumari, Henry 53352 (MH). Madurai, Pulney hills, Collector? s.n. (MH, acc. no. 50130). Nilgiris, Brown 2931 (MH). Salem, Rao 23066 (MH). Tirunelveli, Collector ? 14526 (MH). 


\section{Oberonia anamalayana Joseph - Fig. 13.}

Oberonia anamalayana Joseph, J. Indian Bot. Soc. 42 (1963) 222; Pradhan, Indian Orch. 2 (1979) 694; Abraham \& Vatsala, Intr. Orch. (1981) 425; Ansari et al., J. Econ. Tax. Bot. 3 (1982) 114; Jain \& Mehrotra, Prel. Inv. Orch. India (1984) 94. - T y p e: Joseph 13537, Waverly estate reserve forest, Anamalais, Coimbatore, $1500 \mathrm{~m}, 16 \mathrm{Jan} .1961$ (MH).

Erect or pendulous epiphytes, acaulescent. Leaves articulate at base, up to 21 by $4 \mathrm{~cm}$, oblong, acute, $\tan$ brown. Scape up to $7 \mathrm{~cm}$ long, flattened, adnate to the uppermost leaf. Spike up to $40 \mathrm{~cm}$ long and $1 \mathrm{~cm}$ thick, without any definite sterile tip. Flowers pedicelled, $5.25 \mathrm{~mm}$ long, $2 \mathrm{~mm}$ across, greenish yellow-brown, in verticils $3.5-4 \mathrm{~mm}$ apart. Bracts shorter than the ovary and pedicel, 2.75 by $1.25 \mathrm{~mm}$, oblong, acute, irregularly denticulate along margins, gland-dotted. Sepals \& petals dissimilar, gland-dotted, reflexed; sepals subsimilar, entire; dorsal sepal 2.25 by $0.75 \mathrm{~mm}$, oblong, obtuse; lateral sepals 2.25 by $1 \mathrm{~mm}$, oblong-ovate, obtuse; petals 2.25 by $0.25 \mathrm{~mm}$, linear, obtuse, entire and decurved along margins. Lip reflexed in flower, ovate in outline, 3-lobed, $2.75 \mathrm{~mm}$ long, $2.25 \mathrm{~mm}$ across lateral lobes and $1.25 \mathrm{~mm}$ across midlobe, gland-dotted, glabrous; lateral lobes narrow and longitudinally elongated oblong around the disc, shallowly crenate, spreading in flower, not encircling the column; midlobe 2-lobuled; lobules orbicular, shallowly crenate, diverging; sinus shallow with a rounded protuberance; disc ovate-lanceolate, cushion-like. Ovary \& pedicel $3 \mathrm{~mm}$ long. Column $0.98 \mathrm{~mm}$ long, $0.72 \mathrm{~mm}$ thick, cylindric; clinandrium apical, oblong, saccate; operculum $0.45 \mathrm{~mm}$ long, $0.36 \mathrm{~mm}$ broad, ovate, obtuse at apex; rostellum oblong or orbicular, rounded at apex, projecting beyond the clinandrial wing; stigma suborbicular.

E c o l o g y. Flowering January-March. Altitude $950-1500 \mathrm{~m}$.

Dis tribution. India (Kerala, Tamil Nadu). Endemic to the southern part of Western Ghats.

Specimens examined:

INDIA. Kerala: Idukki, Nair 70113 (MH). Travancore, Bourdillon 78 (MH). Wynad, Thariode, Vatsala s.n. ('KVM', acc. no. nil). Tamil Nadu: Joseph 13537 (CAL, type; MH).

\section{Oberonia zeylanica Hooker f. - Fig. 14.}

Oberonia zeylanica Hooker f., Icon. (1888) 18, t. 1782; Fl. Brit. India 5 (1888) 680; Jayaweera, Dassanayake \& Fosberg, Fl. Ceylon 2 (1981) 10; Ansari et al., J. Econ. Tax. Bot. 3 (1982) 118; Jain \& Mehrotra, Prel. Inv. Orch. India (1984) 99. - T y p e: C.P. 543, Ceylon (K).

Pendulous or erect epiphytes, acaulescent. Leaves articulate at base, up to 16 by $2.2 \mathrm{~cm}$, oblong, acute or subacute. Scape up to $6 \mathrm{~cm}$ long, flattened. Spike up to $12 \mathrm{~cm}$ long, without any definite sterile tip, arcuate. Flowers pedicelled, $4.25 \mathrm{~mm}$ long, $1.75 \mathrm{~mm}$ across, reddish brown, arranged in verticils on the rachis. Bracts shorter than the pedicel and ovary, 1.75 by $1 \mathrm{~mm}$, oblong-lanceolate, acute, irregularly dentate along margins towards apex, gland-dotted. Sepals \& petals dissimilar, reflexed in flower, gland-dotted; sepals subsimilar, 1.75 by $1 \mathrm{~mm}$, induplicate; dorsal sepal ovate, acute; lateral sepals oblong, obtuse; petals 1.5 by $0.25 \mathrm{~mm}$, linear, obtuse, subentire. Lip antrorse, quadrate, $2.25 \mathrm{~mm}$ long, $2 \mathrm{~mm}$ broad, entire and folded upwards laterally with somewhat spreading margins, 2-lobed at apex; lobes somewhat rectangular, truncate and entire at apex, parallel; sinus 
broad with a semiorbicular lobe-like protuberance; disc ovate-oblong, cushion-like. Ovary \& pedicel $2.25 \mathrm{~mm}$ long. Column $0.53 \mathrm{~mm}$ long and thick, subglobose; clinandrium dorsal, suborbicular, minutely winged around, not saccate; operculum $0.42 \mathrm{~mm}$ long, 0.45 $\mathrm{mm}$ broad, suborbicular, obtuse at apex; rostellum ovate-triangular, subacuminate, equalling or little longer than the clinandrial wing; stigma crescent-shaped, saccate; pollinia 0.42 by $0.23 \mathrm{~mm}$, clavate.

E c o log y. Flowering October-January. Altitude 1200-1900 m.

Di s trib u ti o n. India (Tamil Nadu), Sri Lanka.

N o te. There is no recent collection of this plant from India. Jayaweera (1.c.) quoted the specimen Fischer $3263(\mathrm{~K})$ collected from Anamalai hills of Tamil Nadu and the species is included in the present work to reciprocate it.

S pecimens examined:

SRI LANKA. Locality ?, C.P. 3869 (MH).

\section{Oberonia denticulata Wight - Fig. 15.}

Oberonia denticulata Wight, Icon. 5 (1) (1851) 3, t. 1625; Panigrahi \& Dubey, Proc. 8th Ann. Conf. Orissa Bot. Soc. Abstracts 2 (1983) 6 (incl. varieties). - T y p e: Wight s.n., Iyamally hills, Coimbatore (K ?).

Oberonia iridifolia Lindley, Gen. \& Sp. Orch. (1830) 15, p.p. (nom. superfl. et illeg.); Fol. Orch. Oberon. (1859) 1; Hooker f., Fl. Brit. India 5 (1888) 675 (incl. var. denticulata Hooker f., angustifolia Hooker f. and brevifolia Hooker f.); King \& Pantling, Ann. Roy. Bot. Gard. Calcutta 8 (1898) t. 8; Santapau \& Kapadia, Orch. Bombay (1966) 58 (var. denticulata); Seidenf., Dansk Bot. Ark. 25 (3) (1968) 42; ibid. 33 (1) (1978) 16; Pradhan, Indian Orch. 2 (1979) 205 (incl. var.); Abraham \& Vatsala, Intr. Orch. (1981) 416; Ansari et al., J. Econ. Tax. Bot. 3 (1982) 115 (var. denticulata); Jain \& Mehrotra, Prel. Inv. Orch. India (1984) 96; Kataki, Orch. Meghalaya (1986) 23. - T y p e: Wallich 1948-2 (K).

Oberonia gammiei King \& Pantling, J. As. Soc. Bengal II, 66 (1897) 579; Sharma \& Radhakrishnan, J. Bombay Nat. Hist. Soc. 75 (1977) 524 (quoad nom.); Seidenf., Dansk Bot. Ark. 25 (3) (1968) 45. T y p e: Heinig \& Gammie 92, Sunderban, Shella river, Lower Bengal (CAL).

Erect or pendulous epiphytes, acaulescent. Leaves articulate at base, up to 20 by $2 \mathrm{~cm}$, oblong-ensiform, acute. Scape up to $11 \mathrm{~cm}$ long, flattened. Spike up to $30 \mathrm{~cm}$ long and 0.4 $\mathrm{cm}$ thick, without any definite sterile tip. Flowers pedicelled, $2.5 \mathrm{~mm}$ long, $1 \mathrm{~mm}$ across, pale brownish yellow, in verticils $1-2 \mathrm{~mm}$ apart. Bracts equalling or shorter than the pedicel and ovary, 1.25 by $0.75 \mathrm{~mm}$, oblong-lanceolate, acute or obtuse, lacerate or irregularly denticulate along margins, sparsely gland-dotted. Sepals \& petals dissimilar, reflexed; sepals similar, 1 by $0.75 \mathrm{~mm}$, ovate, acute or subacuminate, entire or induplicate along margins; petals 1 by $0.5 \mathrm{~mm}$, ovate, obtuse or subacute, denticulate along margins. Lip antrorse, quadrate or ovate in outline, 3-lobed, $1.5 \mathrm{~mm}$ long, $1.5 \mathrm{~mm}$ across lateral lobes, glabrous or sparsely hairy, gland-dotted; lateral lobes oblong, deeply dentate, spreading in flower except for the incurved distal end; midlobe quadrate in outline, 2-lobuled; lobules oblong or triangular-ovate, acute or obtuse, deeply dentate, parallel or diverging; disc ovate, indistinct. Ovary \& pedicel $1.5 \mathrm{~mm}$ long, glabrous. Column $0.45 \mathrm{~mm}$ long and thick, subglobose; clinandrium apical, orbicular, minutely and uniformly winged around; operculum $0.23 \mathrm{~mm}$ long, $0.3 \mathrm{~mm}$ broad, ovate, acute at apex; rostellum minute, like a triangular protuberance; stigma crescent-shaped or semiorbicular; pollinia 0.21 by $0.15 \mathrm{~mm}$, obovoid.

Ec o lo g y. Flowering September-November. Altitude 25-1400 m. 
D i s tri b u ti o n. India (Andaman Islands, Kerala, Maharashtra, Meghalaya, Nagaland, Sikkim, West Bengal), Australia, Borneo, Burma, Cochinchina, Hainan, Java, Malaya, Nepal, Philippines, Sumatra, Thailand.

Not e s. 1. As stated by Panigrahi \& Dubey (1.c.) the name Oberonia iridifolia Lindley has to be treated as superfluous and illegitimate (vide Article 7.11 and 63.1 of the International Code of Botanical Nomenclature, 1983) since Lindley included Malaxis ensiformis J.E. Smith (in Rees' Cyclop. 22, 1812, no. 14) as a direct taxonomic synonym in the protologue of $O$. iridifolia.

2. We could examine specimens determined by earlier workers as different varieties of Oberonia iridifolia, viz. var. angustifolia, brevifolia, denticulata and iridifolia and the species $O$. gammiei, but could not find any major difference among them. The specimen (Sharma 43932) which Sharma \& Radhakrishnan (1.c.) identified as O. gammiei and reported from Kerala, is now found to be $O$. brachyphylla. Seidenfaden (1968) felt that $O$. gammiei can be conspecific with $O$. lobulata, but is now fully convinced that the terete scape, prominent rostellum and the lunate stigma in $O$. lobulata are contrasting with those in O. gammiei ( $=0$. denticulata).

Specimens examined:

INDIA. Andaman Islands: Balakrishnan 5492 (PBL). Kerala: Cannanore, Barber 6482 (MH). Idukki, Deb 30458 (MH). Kasaragod, Ansari 64869 (MH). Quilon, Mohanan 61116 (MH). Meghalaya: K \& J Hills, Upendranath Kanjilal 4573 (ASSAM). Nongpoh, Joseph 45632 (ASSAM). Nagaland: Malhotra 74970 (ASSAM). Sikkim: King 3085 (CAL). West Bengal: Sundarbans, Heinig \& Gammie 92 (CAL, type of O. gammiei).

\section{SECTION IV}

\section{KEY TO THE SPECIES OF SECTION IV}

1a. Flowers subsessile, closely adpressed to the rachis; lip not lobed.

16. O. maxima Hooker f.

b. Flowers pedicelled, not adpressed to the rachis; lip 3-lobed . . . . . . . . . . 2

2a. Lateral lobes of lip prominent, not auricular $\ldots \ldots \ldots \ldots \ldots \ldots \ldots$

b. Lateral lobes of lip not prominent, auricular $\ldots \ldots \ldots \ldots \ldots \ldots$

3a. Inflorescence longer than the leaves; lip glabrous; disc ovate or indistinct . . . . . . 4

b. Inflorescence shorter than the leaves; lip papillose; disc represented by a cushion-like mesochil between the lateral lobes and midlobe 2. O. ensiformis (Smith) Lindley

4a. Leaves narrowing towards base from the middle; lateral lobes of the lip not wing-like on spreading $\ldots \ldots \ldots \ldots \ldots \ldots \ldots \ldots \ldots \ldots \ldots \ldots \ldots \ldots \ldots \ldots \ldots \ldots$

b. Leaves not narrowing towards base; lateral lobes of the lip wing-like on spreading 5

5a. Lobules of midlobe oblong or cuneate, parallel; clinandrium dorsal; stigma broadly winged around . . . . . . . . . . . . . . 21. 0. acaulis Griff.

b. Lobules of midlobe ligulate, diverging; clinandrium apical; stigma not winged around 6 
6a. Lateral lobes of lip oblong or ligulate, bend upwards and interlocking by their tips enclosing the column; petals linear .......... 19. O. wightiana Lindley

b. Lateral lobes of lip ovate, folded inward and pointing forward, not interlocking by their tips, exposing the column; petals oblong-elliptic or oblanceolate.

20. O. myriantha Lindley

7a. Lateral lobes of lip lacerate or dentate along margins; lobules of midlobe triangular; rostellum projecting beyond the clinandrial wing; bracts irregularly dentate along margins ................. 17. O. lobulata King \& Pantling

b. Lateral lobes of lip entire along margins; lobules of midlobe oblong or ligulate; rostellum equalling the clinandrial wing; bracts subentire ... 18. O. arnottiana Wight

8a. Lobules of midlobe distantly toothed or serrate, truncate or rounded at apex . . . 9

b. Lobules of midlobe entire, acute at apex . . . . . . . . . . . . 10

9a. Column winged laterally at the region of the stigma; rostellum triangular, acuminate; clinandrium dorsal, not saccate; operculum vertically elongated oblong; pollinia curved; sepals sparsely papillose . . . . . . . . . 23. O. thwaitesii Hooker f.

b. Column not winged laterally; rostellum rounded, obtuse; clinandrium apical, saccate; operculum suborbicular; pollinia not curved; sepals glabrous.

24. 0 . verticillata Wight

10a. Leaves oblong-lanceolate; lobules of midlobe parallel; disc cushion-like; lateral lobes of lip spreading in flower . . . . . . . . . 25. O. falconeri Hooker $f$.

b. Leaves linear; lobules of midlobe diverging; disc indistinct; lateral lobes of lip bend

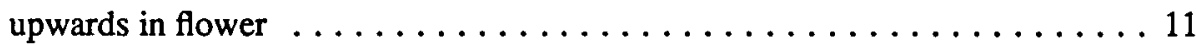

11a. Petals spreading in flower; bracts longer than the pedicel and ovary; column winged laterally; plants often caulescent ........27. 0 . caulescens Wall. ex Lindley

b. Petals reflexed in flower; bracts equalling the pedicel and ovary; column not winged; plants never caulescent ..............26. 0 . pyrulifera Lindley

\section{Oberonia maxima Hooker f. - Fig. 16.}

Oberonia maxima Hooker f., Fl. Brit. India 5 (1888) 677; Deori \& Hajra, Bull. Bot. Surv. India 17 (1975) 170; Jain \& Mehrotra, Prel. Inv. Orch. India (1984) 97. - T y p e: Parish 287, Moulmein, Burma (K).

Erect or pendulous epiphytes, acaulescent. Leaves articulate at base, up to 28 by 2.5 $\mathrm{cm}$, ensiform, subacuminate. Scape up to $8 \mathrm{~cm}$ long, $0.2 \mathrm{~cm}$ across, much shorter than the leaves, terete. Spike up to $12 \mathrm{~cm}$ long, $0.5 \mathrm{~cm}$ across, fleshy. Flowers subsessile, $2.5 \mathrm{~mm}$ long, $1.25 \mathrm{~mm}$ across, yellowish-green, in close verticils, closely adpressed to the rachis. Bracts longer than the ovary, 2 by $1.5 \mathrm{~mm}$, oblong, acute, lacerate along margins, glanddotted. Sepals \& petals dissimilar, reflexed in flower, sparsely gland-dotted; sepals subsimilar; dorsal sepal 1.25 by $1 \mathrm{~mm}$, ovate, acute, entire; lateral sepals 1 by $0.75 \mathrm{~mm}$, obliquely ovate, acute, entire; petals 1 by $0.5 \mathrm{~mm}$, ovate, obtuse, minutely and distantly dentate along margins. Lip antrorse, suborbicular, not lobed, $1 \mathrm{~mm}$ long, $1.5 \mathrm{~mm}$ broad, obtuse, crenate along margins, gland-dotted; disc ovate, cushion-like. Ovary $1.5 \mathrm{~mm}$ long. 
Column $0.5 \mathrm{~mm}$ long, $0.45 \mathrm{~mm}$ thick, obovoid or subglobose; clinandrium apical, orbicular, winged around, saccate; operculum $0.33 \mathrm{~mm}$ long, $0.41 \mathrm{~mm}$ broad, ovate-suborbicular, acute at apex; rostellum triangular, acuminate, projecting beyond the clinandrial wing; stigma crescent-shaped; pollinia 0.26 by $0.18 \mathrm{~mm}$, obovoid.

Ecolog y. Flowering June-September.

Dis tribution. India (Anunachal Pradesh, Meghalaya, Nagaland), Burma.

Specimens examined:

INDIA. Nagaland: Khonoma, Hynniewta 74523 (ASSAM).

\section{Oberonia lobulata King \& Pantling - Fig. 17.}

Oberonia lobulata King \& Pantling, Ann. Roy. Bot. Gard. Calcutta 8 (1898) 4; Seidenf., Dansk Bot. Ark. 25 (3) (1968) 33; Pradhan, Indian Orch. 2 (1979) 194; Jain \& Mehrotra, Prel. Inv. Orch. India (1984) 97. - T y p e: Pantling 199, Tista Valley, Sikkim (CAL).

Erect or pendulous epiphytes, acaulescent. Leaves articulate at base, up to 8 by $1.2 \mathrm{~cm}$, oblong-elliptic, acute. Scape up to $3.5 \mathrm{~cm}$ long, terete. Spike up to $10.5 \mathrm{~cm}$ long. Flowers (buds) pedicelled, green. Bracts longer than the ovary and pedicel 1.5 by $0.75 \mathrm{~mm}$, oblong, subacute, irregularly dentate along margins, gland-dotted.Sepals \& petals dissimilar; sepals similar, 1 by $0.75 \mathrm{~mm}$, oblong-ovate, obtuse, entire, not gland-dotted; petals 0.75 by $0.25 \mathrm{~mm}$, oblong-ovate, obtuse, subentire, sparsely gland-dotted. Lip ovate or quadrate in outline, 3 -lobed, $1 \mathrm{~mm}$ long, $1 \mathrm{~mm}$ across lateral lobes and $0.5 \mathrm{~mm}$ across midlobe, gland-dotted; lateral lobes oblong, lacerate or irregularly dentate along margins; midlobe quadrate, subentire, 2-lobuled; lobules minute, triangular, acute, diverging; sinus broad; disc not distinct. Ovary \& pedicel $0.75 \mathrm{~mm}$ long. Column $0.41 \mathrm{~mm}$ long, $0.45 \mathrm{~mm}$ thick, subglobose; clinandrium apical, orbicular, winged around, saccate; rostellum ovate, obtuse at apex, longer than the clinandrial wing; stigma crescent-shaped.

Ecolog y. Flowering October. Altitude about $300 \mathrm{~m}$.

Dis tribution. India (Sikkim). Endemic to this region.

Specimens examined:

INDIA. Sikkim: Pantling 199 (CAL, type).

\section{Oberonia arnottiana Wight - Fig. 18.}

Oberonia arnottiana Wight, Icon. 5 (1) (1851) 3, t. 1628. - Oberonia wightiana Lindley var. arnottiana (Wight) Ansari et al., J. Econ. Tax. Bot. 3 (1982) 118. - T y p e: Wight s.n., Neilgherries (BM, lecto).

Oberonia wightiana Lindley var. nilgirensis Ansari et al., J. Econ. Tax. Bot. 3 (1982) 118 - T y p e: Sharma 35978, Nilgiris, 1.9.1970 (CAL, holo; MH).

Pendulous or erect epiphytes, acaulescent. Leaves articulate at base, up to 9 by $1 \mathrm{~cm}$, oblanceolate or elliptic, mostly falcate, acute, narrowed towards base. Scape up to $4.5 \mathrm{~cm}$ long, terete. Spike up to $15 \mathrm{~cm}$ long, mostly pendulous. Flowers pedicelled, $2.5-3.5 \mathrm{~mm}$ long, 1.5-2 mm across, pale or brownish yellow, in verticils or scattered. Bracts equalling or longer than the ovary and pedicel, 1.75 by $0.75 \mathrm{~mm}$, ovate, acuminate or subacute, subentire, sparsely gland-dotted. Sepals \& petals dissimilar, sparsely gland-dotted, reflexed; sepals subsimilar, 1 by $0.75 \mathrm{~mm}$, ovate, acute, entire; petals 1 by $0.25 \mathrm{~mm}$, linear, obtuse, entire. Lip antrorse, quadrate in outline, 3-lobed, $2 \mathrm{~mm}$ long, $1.75 \mathrm{~mm}$ across lateral lobes and $1.5 \mathrm{~mm}$ across midlobe, gland-dotted or not; lateral lobes longitudinally elongated 
oblong around the disc, entire, folded upwards but not interlocking by their tips; midlobe 2-lobuled with a conical protuberance in between; lobules oblong or ligulate, entire, acute or truncate and variously toothed at apex, diverging; disc ovate, indistinct. Ovary \& pedicel 1-1.5 mm long. Column $0.27 \mathrm{~mm}$ long, $0.26 \mathrm{~mm}$ thick, subglobose; clinandrium apical, orbicular, winged around, saccate; operculum $0.24 \mathrm{~mm}$ long, $0.39 \mathrm{~mm}$ broad, laterally elongated oblong, truncate at apex; rostellum equalling the clinandrial wing, rounded; stigma crescent-shaped; pollinia 0.20 by $0.15 \mathrm{~mm}$, obovoid.

E c o lo g y. Flowering September-November. Altitude 2000-2500 m.

D i s tr i b u t i o n. India (Kerala, Tamil Nadu, Uttar Pradesh), Sri Lanka.

Note. While establishing this species Wight (1.c.) wrote that the two species (Oberonia arnottiana and $O$. wightiana) were mixed in the collection which was named as O. wightiana by Lindley (Bot. Reg. 25, Misc. 9, 1839). Later, Lindley (1859) merged $O$. arnottiana with his $O$. wightiana saying 'this seems to vary more than usual in the present genus, in the form of its lip ...' Subsequent workers followed Lindley. Ansari et al. (l.c.) while analysing the lip characters recognised three varieties for the species $O$. wightiana, viz. vars. arnottiana, nilgirensis and wightiana. After examining a number of specimens including the one cited by Lindley (C.P. 2506) and the lectotype of $O$. wightiana (Wight 181 ), the two species ( $O$. arnottiana Wight and $O$. wightiana Lindley) are now further distinguished with certainty. However, the var. nilgirensis Ansari et al. is considered as a variant of $O$. arnottiana.

S pecimens examined:

INDIA. Kerala: Anaimudi, Shetty 33426 (MH). Umaiya Mala, Shetty $26468(\mathrm{MH})$. Tamil Nadu: Coimbatore, Anamalais, Barber 4028 (MH). Nilgiris, Ellis 43394 (MH); Sharma 35978 (MH, type of O. wightiana var. nileirensis). Uttar Pradesh: Pithoragarh, Arora 55804 AA (BSD).

SRI LANKa. Place?, C.P. $2506(\mathrm{MH})$.

\section{Oberonia wightiana Lindley - Fig. 19.}

Oberonia wightiana Lindley, Bot. Reg. 25, Misc. (1839) 9; Wight, Icon. 5 (1) (1851) 3, t. 1627; Lindley, Fol. Orch. Oberon. (1859) 5, p.p.; Hooker f., Fl. Brit. India 5 (1888) 683, p.p.; Santapau \& Kapadia, Orch. Bombay (1966) 67 (quoad nom.); Seidenf., Dansk Bot. Ark. 25 (3) (1968) 28, p.p.; Pradhan, Indian Orch. 2 (1979) 203; Ansari et al., J. Econ. Tax. Bot. 3 (1982) 117 (excl. vars. arnottiana and nilgirensis); Joseph, Orch. Nilgiris (1982) 87; Jain \& Mehrotra, Prel. Inv. Orch. India (1984) 99. $\mathrm{T}$ y p e: Wight 181 , Ind. Orient. (K, lecto; $\mathrm{MH}$ ).

Mostly pendulous epiphytes, acaulescent. Leaves articulate at base, up to 15 by $1 \mathrm{~cm}$, oblong-ensiform, acute. Scape up to $7 \mathrm{~cm}$ long, terete. Spike up to $15 \mathrm{~cm}$ long. Flowers pedicelled, $3.5 \mathrm{~mm}$ long, $1.5 \mathrm{~mm}$ across, pale or orange yellow, scattered on the rachis. Bracts 1.5 by $0.75 \mathrm{~mm}$, ovate-lanceolate, acuminate or subacute, subentire or dentate along margins, sparsely gland-dotted. Sepals \& petals dissimilar, glabrous, reflexed; sepals subsimilar, 1 by $0.5 \mathrm{~mm}$; dorsal sepal oblong, obtuse, entire; lateral sepals ovate-oblong, subacute, induplicate; petals 1 by $0.25 \mathrm{~mm}$, linear, obtuse, entire. Lip antrorse, quadrate or ovate in outline, 3 -lobed, $1.5 \mathrm{~mm}$ long, $2 \mathrm{~mm}$ across lateral lobes and 1-2 mm across midlobe; lateral lobes oblong-ligulate, wing-like on spreading, rounded at tips, entire, folded upwards round the column and interlocking by their tips; midlobe 2-lobuled; lobules ligulate, entire, oblique and variously toothed at apex, diverging; disc ovate, not distinct. Ovary \& pedicel $2 \mathrm{~mm}$ long. Column $0.45 \mathrm{~mm}$ long, $0.35 \mathrm{~mm}$ thick, cylindric; clinandrium 
apical, oblong, not saccate; operculum $0.2 \mathrm{~mm}$ long, $0.29 \mathrm{~mm}$ broad, laterally elongated oblong, obtuse or retuse at apex; rostellum equalling the clinandrial wing, obtuse; stigma crescent-shaped; pollinia 0.17 by $0.09 \mathrm{~mm}$, obovoid.

N o te. The specimen which Santapau \& Kapadia (1.c.) included under $O$. wightiana is probably $O$. recurva.

Ec ol o g y. Flowering August-November. Altitude 1900-2500 m.

Dis tribution. India (Tamil Nadu). Endemic to southern part of Western Ghats.

Specimens examined:

INDIA. Tamil Nadu: Kodaikanal, Barber 7523 (MH). Nilgiris, Wight 181 (MH, type). Salem, Shevaroys, Rao $23068(\mathrm{MH})$.

\section{Oberonia myriantha Lindley - Fig. 20.}

Oberonia myriantha Lindley, Fol. Orch. Oberon. (1859) 4; Hooker f., Fl. Brit. India 5 (1888) 679, p.p. (excl. syn. Oberonia acaulis Griff.); Seidenf., Dansk Bot. Ark. 25 (3) (1968) 56, p.p.; Pradhan, Indian Orch. 2 (1979) 198 (quoad nom.); Kataki, Orch. Meghalaya (1986) 27, p.p. - T y p e: Hooker f. \& Thomson 113, Khasia (K, holo; MH).

Oberonia sikkimensis Lindley, Fol. Orch. Oberon. (1859) 4. - T y p e: J.D. Hooker 114, Sikkim (K ?). Oberonia ritaii King \& Pantling, J. As. Soc. Bengal II, 66 (1897) 579; Seidenf., Dansk Bot. Ark. 25 (3)

(1968) 58. - T y p e: Rita 599, Jowai, Assam, Aug. 1896 (CAL).

Epiphytes, mostly pendulous, acaulescent. Leaves articulate at base, up to 13 by 0.8 $\mathrm{cm}$, oblong-ensiform, acuminate. Scape up to $3 \mathrm{~cm}$ long, terete. Spike up to $24 \mathrm{~cm}$ long. Flowers pedicelled, $2.5 \mathrm{~mm}$ long, $1.75 \mathrm{~mm}$ across, pale or brownish yellow, in verticils $2.5 \mathrm{~mm}$ apart. Bracts longer than the ovary and pedicel, 2.5 by $0.75 \mathrm{~mm}$, lanceolate, acuminate, irregularly dentate along margins. Sepals \& petals dissimilar, spreading; sepals sub-similar, 0.75 by $0.5 \mathrm{~mm}$, oblong-ovate, entire, obtuse, minutely keeled on back at apex; petals $0.75-1.25$ by $0.5 \mathrm{~mm}$, oblong-elliptic or oblanceolate, obtuse, subentire, gland-dotted. Lip antrorse, quadrate in outline, 3-lobed, $1.25 \mathrm{~mm}$ long, $1.25 \mathrm{~mm}$ across lateral lobes and $0.75 \mathrm{~mm}$ across midlobe, gland-dotted; lateral lobes ovate, obtuse, winglike on spreading, bend inwards in flower but not encircling the column, entire; midlobe obovate, 2-lobuled; lobules ligulate, truncate or acute at apex, subentire along margins, diverging; sinus broad with a triangular protuberance; disc ovate, indistinct. Ovary \& pedicel $1.75 \mathrm{~mm}$ long. Column $0.27 \mathrm{~mm}$ long, $0.24 \mathrm{~mm}$ thick, cylindric; clinandrium apical, orbicular, minutely winged around; operculum $0.18 \mathrm{~mm}$ long, $0.27 \mathrm{~mm}$ broad, laterally elongated oblong, subacute at apex; rostellum triangular, acuminate, projecting beyond the clinandrial wing; stigma minute, orbicular; pollinia 0.17 by $0.14 \mathrm{~mm}$, obovoid.

E c o lo g y. Flowering August-November. Altitude 600-2000 m.

D i s $\mathrm{r}$ i b u t i o n. India (Manipur, Meghalaya, Nagaland), Burma?, China?, Vietnam?.

Note s. 1. Hooker f. (1.c.) considered Oberonia sikkimensis Lindley and O. acaulis Griff. to be conspecific with Lindley's species $O$. myriantha and adopted the name $O$. myriantha for it. The subsequent workers followed Hooker. Seidenfaden (1978) recognised the priority of Griffith's name $O$. acaulis over the others, but he accepted Hooker's concept of its conspecificity.

2. While analysing the specimens for the present work, two different species were found mixed up in the herbaria which could be separated mainly by the structure of the column. 
The plants of $O$. myriantha have a cylindric column with an apical clinandrium and a small stigma and the flowers arranged in clear verticils. The other species with the disciform column, the dorsal clinandrium and a broad and winged stigma is found agreeing with the illustration of Griffith for his $O$. acaulis.

3. Oberonia sikkimensis Lindley with 'flowers more or less perfectly verticillate' is felt conspecific with $O$. myriantha. All the specimens which were earlier determined as $O$. ritaii and kept in Indian Herbaria are found to be 0 . myriantha.

4. The specimens from other countries need further study for their correct determination based on the present concept.

S pecimens examined:

INDIA. Manipur: Meebold 6642 (MH). Meghalaya: Jarain, Hynniewta 53073 (ASSAM). Jowai, Rita 599 (CAL, type of $O$. ritaii). Khasia, Hooker $f$. \& Thomson 113 (MH, type). Nagaland: Hynniewta 56306 (ASSAM).

\section{Oberonia acaulis Griff. - Fig. 21 .}

Oberonia acaulis Griff., Itin. Not. (1848) 76; Icon. (1851) t. 286, f. 1; Seidenf., Dansk Bot. Ark. 33 (1) (1978) 20, p.p. (excl. synonyms); Jain \& Mehrotra, Prel. Inv. Orch. India (1984) 94. - T y p e: Griffith 1130, Churra (K ?).

Epiphytes, mostly pendulous, acaulescent. Leaves articulate at base, up to 28 by $1 \mathrm{~cm}$, oblong-ensiform, acuminate. Scape up to $6 \mathrm{~cm}$ long, terete. Spike up to $35 \mathrm{~cm}$ long, 0.6 $\mathrm{cm}$ across. Flowers pedicelled, $3 \mathrm{~mm}$ long, $2 \mathrm{~mm}$ across, yellowish or rusty brown, scattered on the rachis. Bracts longer than the ovary and pedicel, 2 by $0.75 \mathrm{~mm}$, lanceolate, acuminate, irregularly dentate along margins. Sepals \& petals dissimilar, reflexed, sparsely gland-dotted; sepals dissimilar, minutely keeled on back at apex; dorsal sepal 1 by $0.5 \mathrm{~mm}$, oblong-elliptic, obtuse, entire; lateral sepals 1 by $0.75 \mathrm{~mm}$, obliquely ovate, subacuminate, induplicate; petals 1 by $0.5 \mathrm{~mm}$, oblong-lanceolate, obtuse, subentire. Lip antrorse, quadrate in outline, 3-lobed, $1.5 \mathrm{~mm}$ long, $1.25 \mathrm{~mm}$ across lateral lobes and $1 \mathrm{~mm}$ across midlobe, densely marked with irregular glands; lateral lobes oblong-cuneate, wing-like, spreading in flower, entire or subentire; midlobe oblong or obovate, 2-lobuled; lobules oblong or cuneate, rounded or subtruncate at apex, subentire along margins, parallel to each other; sinus narrow, without any protuberance in between; disc ovate or obovate, indistinct. Ovary \& pedicel $1.25 \mathrm{~mm}$ long. Column $0.45 \mathrm{~mm}$ long, $0.38 \mathrm{~mm}$ broad, disciform; clinandrium dorsal, orbicular, broader than the column stalk, winged around; operculum $0.3 \mathrm{~mm}$ long, $0.33 \mathrm{~mm}$ broad, ovate-orbicular, subacute at apex; rostellum ovate, obtuse; stigma $0.38 \mathrm{~mm}$ in diameter, orbicular, winged around; pollinia 0.21 by $0.14 \mathrm{~mm}$, obovoid.

E c o lo g y. Flowering July-December. Altitude $1300-2300 \mathrm{~m}$.

D i s $\mathrm{r}$ i b u t i o n. India (Arunachal Pradesh, Assam, Meghalaya, Nagaland, Sikkim, Uttar Pradesh), Bhutan.

S pecimens examined:

INDIA. Arunachal Pradesh: Lohit Dist., Krishna 48733 (CAL). Assam: Anima Das s.n. (ASSAM, acc. no. 35362). Meghalaya: Khasia hills, Dr. Prain's collector 192 (MH). K. \& J. Hills, Kataki 34325 (ASSAM). Shillong, Rao 22695 (ASSAM). Nagaland: Hynniewta 80400 (ASSAM). Uttar Pradesh: Arora 66274 (BDS). Sikkim: Namgah, Pantling 195 (CAL).

BHUTAN. Locality ?, Balakrishnan 44138 (ASSAM). 


\section{Oberonia ensiformis (Smith) Lindley - Fig. 22.}

Oberonia ensiformis (Smith) Lindley, Fol. Orch. Oberon. (1859) 4; Hooker f., Fl. Brit. India 5 (1888) 679; Duthie, Ann. Roy. Bot. Gard. Calcutta 9 (2) (1906) 86; Santapau \& Kapadia, Orch. Bombay (1966) 58; Seidenf., Dansk Bot. Ark. 25 (3) (1968) 53; ibid. 33 (1) (1978) 13; Pradhan, Indian Orch. 2 (1979) 202; Abraham \& Vatsala, Intr. Orch. (1981) 419; Ansari et al., J. Econ. Tax. Bot. 3 (1982) 115; Jain \& Mehrotra, Prel. Inv. Orch. India (1984) 96. - Malaxis ensiformis Smith, Rees' Cyclop. 22 (1812) no. 14. - T y p e: Hamilton-Buchanan s.n., Narainhetty, Nepal (LINN).

Epiphytes, mostly pendulous, acaulescent. Leaves articulate at base, up to 45 by 1.8 $\mathrm{cm}$, ensiform, acute or acuminate. Scape up to $10 \mathrm{~cm}$ long, terete. Spike up to $15 \mathrm{~cm}$ long, $0.5 \mathrm{~cm}$ across. Flowers pedicelled, $3.25 \mathrm{~mm}$ long, $1.5 \mathrm{~mm}$ across, pale or brownish yellow, in verticils 2-5 mm apart. Bracts longer than the pedicel and ovary, 2.25 by $1.5 \mathrm{~mm}$, ovate, acute, irregularly dentate along margins, induplicate, reflexed at apex, gland-dotted. Sepals \& petals dissimilar, reflexed, gland-dotted; sepals dissimilar, entire; dorsal sepal 1.25 by $0.75 \mathrm{~mm}$, ovate, acute; lateral sepals 1 by $1.25 \mathrm{~mm}$, broadly and obliquely ovate, acute; petals 1.25 by $0.75 \mathrm{~mm}$, ovate-lanceolate, obtuse, irregularly dentate along margins, papillose. Lip antrorse, quadrate in outline, with two minute calli at base, 3-lobed, $1.75 \mathrm{~mm}$ long, $1.5 \mathrm{~mm}$ across both lateral lobes and midlobe, gland-dotted, papillose; lateral lobes rounded or cuneate, wing-like and spreading in flower, midlobe obreniform, 2-lobuled, separated from the lateral lobes by an elongated, glabrous mesochil; lobules rounded, converging; sinus broad, without any protuberance; disc represented by the mesochil which has two rounded calli laterally at base and a median longitudinal groove. Ovary \& pedicel $1.75 \mathrm{~mm}$ long, glabrous. Column $0.36 \mathrm{~mm}$ long, $0.53 \mathrm{~mm}$ thick, subglobose; clinandrium dorsal, winged ventrally only, suborbicular; operculum $0.35 \mathrm{~mm}$ long, $0.39 \mathrm{~mm}$ broad, ovate-orbicular, acute at apex; rostellum equalling the clinandrial wing, triangular, acute; stigma semiorbicular, not saccate; pollinia 0.23 by $0.17 \mathrm{~mm}$, obovoid-oblong.

E c o 10 g y. Flowering September-January. Altitude 500-2000 m.

Di s tri b u t i o n. India (Andhra Pradesh, Karnataka, Kerala, Maharashtra, Meghalaya, Sikkim, Tamil Nadu, Uttar Pradesh), Burma, China, Nepal, Thailand, Vietnam.

$\mathrm{N}$ o t e. The specimen Dalzell s.n. deposited in DD, identified as Oberonia ferruginea Parish is on thorough examination found to be $O$. ensiformis itself.

S pecimens examined:

INDIA. Andhra Pradesh: Visakhapatnam, Ellis 37179 (MH). Karnataka: Mysore, Rao 73593 (BSI). Kerala, Sebastine 15668 (MH). Locality ?, Dalzell s.n. (DD). Meghalaya: K. \& J. Hills, Das s.n. (ASSAM, acc. no. 35348). Sikkim: Gharual, King s.n. (CAL, acc. no. 449590). Kumai, Pantling 305 (CAL). Tamil Nadu, Ramamurthy 23448 (MH). Uttar Pradesh: Garhwal hills, Coll. Mayat 25833 (DD). Kumaon, Arora 66131 (BSD).

\section{Oberonia thwaitesii Hooker f. - Fig. 23.}

Oberonia thwaitesii Hooker f., Fl. Brit. India 5 (1888) 678; Jayaweera in Dassanayake \& Fosberg, Fl. CeyIon 2 (1981) 23; Manilal \& Kumar, Curr. Sci. 53 (1984) 1106. - T y p e: C.P. 2572, Ceylon (PDA, lecto; MH).

Oberonia verticillata var. pubescens Lindley, Fol. Orch. Oberon. (1859) 3. - T y p e: Thwaites 2516, Ceylon (K, holo; $\mathrm{MH})$.

Erect or pendulous epiphytes, acaulescent. Leaves articulate at base, up to 10 by $1 \mathrm{~cm}$, oblong-ensiform, straight or slightly curved, acute. Scape indistinct. Spike up to $23 \mathrm{~cm}$ 
long. Flowers pedicelled, $2.5 \mathrm{~mm}$ long, $1.5 \mathrm{~mm}$ across, pale orange-yellow, in verticils $3.5-4.5 \mathrm{~mm}$ apart. Bracts slightly longer than the ovary and pedicel, 1.75 by $0.75 \mathrm{~mm}$, oblong or oblong-lanceolate, acute, irregularly toothed along margins, sparsely glanddotted. Sepals \& petals refiexed, sparsely gland-dotted; sepals dissimilar, sparsely papillose outside, induplicate; dorsal sepal 0.75 by $0.5 \mathrm{~mm}$, ovate, acute; lateral sepals 0.75 by $0.75 \mathrm{~mm}$, obliquely ovate, petals 0.75 by $0.5 \mathrm{~mm}$, ovate, subacute, subentire, glabrous. Lip antrorse, obovate in outline, 3-lobed, $1.5 \mathrm{~mm}$ long, $1.25 \mathrm{~mm}$ across midlobe, glanddotted, glabrous; lateral lobes rounded, auricular, folded upwards in flower but not encircling the column; midlobe 2-lobuled; lobules oblong or cuneate, distantly toothed along margins, almost parallel; disc indistinct. Ovary \& pedicel $1.5 \mathrm{~mm}$ long. Column $0.35 \mathrm{~mm}$ long, $0.41 \mathrm{~mm}$ thick, subglobose, minutely winged at the junction of the stigma; clinandrium dorsal, wider than the column stalk, winged around, orbicular, not saccate; operculum $0.3 \mathrm{~mm}$ long, $0.24 \mathrm{~mm}$ broad, oblong, rounded at apex; rostellum narrowly triangular, acuminate, projecting beyond the clinandrial wing; stigma semiorbicular, pollinia 0.17 by $0.09 \mathrm{~mm}$, clavate, curved.

Ec o log y. Flowering June-August. Altitude 500-1000 m.

Dis tribution. India (Kerala), Sri Lanka.

N o t e. This plant was believed to be endemic to Sri Lanka, until Manilal \& Sathish Kumar (l.c.) reported it from Western Ghats. But their voucher specimen, Sivadasan 15255 , is found missing in the herbarium (CALI).

Specimens examined:

SRI LANKA. Locality ?, C.P. 2572 (MH, type).

\section{Oberonia verticillata Wight - Fig. 24.}

Oberonia verticillata Wight, Icon. 5 (1) (1851) 3, t. 1626; Lindley, Fol. Orch. Oberon. (1859) 3 (excl. vars. pubescens, khasiana and gigantea); Hooker f., Fl. Brit. India 5 (1888) 677; Santapau \& Kapadia, Orch. Bombay (1966) 66; Seidenf., Dansk Bot. Ark. 25 (3) (1968) 30; Pradhan, Indian Orch. 2 (1979) 194; Abraham \& Vatsala, Intr. Orch. (1981) 419; Ansari et al., J. Econ. Tax. Bot. 3 (1982) 117; Joseph, Orch. Nilgiris (1982) 88; Jain \& Mehrotra, Prel. Inv. Orch. India (1984) 99. - T y p e: Wight s.n., Neilgherries (BM, lecto).

Oberonia verticillata var. longibracteata Blatt. \& McCann, J. Bombay Nat. Hist. Soc. 35 (1931) 255. T y p e: Bell 3908, Yellapur, 1500 ft., N. Kanara (BLAT).

Oberonia spiralis Blatt. \& McCann, J. Bombay Nat. Hist. Soc. 35 (1931) 256 (non Griff. 1851, nec. Lindley 1852). - T y p e: Bell 219, Yellapur, N. Kanara (BLAT).

Oberonia bellii Blatt. \& McCann, J. Bombay Nat. Hist. Soc. 35 (1931) 256; Santapau \& Kapadia, Orch. Bombay (1966) 75; Jain \& Mehrotra, Prel. Inv. Orch. India (1984) 95. - T y p e: Not designated.

Pendulous epiphytes, acaulescent. Leaves articulate at base, up to 15 by $1.2 \mathrm{~cm}$, oblongensiform, acute or subacuminate. Scape up to $3 \mathrm{~cm}$ long, terete. Spike up to $27 \mathrm{~cm}$ long, pendulous. Flowers pedicelled, $4-4.5 \mathrm{~mm}$ long, $2 \mathrm{~mm}$ across, pale or orange yellow, in verticils 5-15 mm apart; verticils becoming more distant towards the tip of the spike. Bracts equalling or longer than the ovary and pedicel, 2.5 by $0.75 \mathrm{~mm}$, ovate-lanceolate, acuminate, irregularly dentate along margins, sparsely gland-dotted. Sepals \& petals dissimilar, sparsely gland-dotted, glabrous, reflexed; sepals dissimilar, entire and induplicate; dorsal sepal 1.25 by $0.75 \mathrm{~mm}$, oblong-ovate, obtuse; lateral sepals 1 by $0.75 \mathrm{~mm}$, obliquely ovate, acute or subacuminate; petals 1.25 by $0.75 \mathrm{~mm}$, oblong or ovate, obtuse or acute, subentire. Lip antrorse, cuneate-obovate in outline, 3-lobed, $2.25 \mathrm{~mm}$ long, $1.25 \mathrm{~mm}$ 
across lateral lobes and $2 \mathrm{~mm}$ across midlobe, gland-dotted; lateral lobes rounded, auriculate, folded upwards or spreading in flower, not encircling the column; the midlobe 2-lobuled; lobules orbicular, obovate or oblong, distantly serrate along margins, overlapping each other or parallel; sinus narrow; disc indistinct. Ovary \& pedicel 2-2.5 mm long. Column $0.53 \mathrm{~mm}$ long and $0.68 \mathrm{~mm}$ thick, subglobose; clinandrium apical, orbicular, winged around, saccate; operculum $0.33 \mathrm{~mm}$ long and $0.38 \mathrm{~mm}$ broad, suborbicular, obtuse at apex; rostellum rounded, obtuse; stigma crescent-shaped; pollinia 0.24 by $0.15 \mathrm{~mm}$, obovoid.

E c o 10 g y. Flowering September-January. Altitude 500-2200 m.

D i s $t r$ i b u t i o n. India (Karnataka, Kerala, Maharashtra, Tamil Nadu). Endemic to Western Ghats and Salem hills.

$\mathrm{N}$ ot e. Most of the earlier workers believed that this species is having its distribution over to Ceylon. But Jayaweera, (1981) did not include this species. The specimen from Ceylon (Thwaites 2572) which Seidenfaden (1.c.) examined is the lectotype of Oberonia thwaitesii (vide Jayaweera, 1.c.).

As mentioned by Santapau \& Kapadia (1966) $O$. bellii was described from Bell's manuscript notes and the actual type is not available. They felt that $O$. bellii is identical with $O$. verticillata. In the absence of any specimen in the Indian herbaria, their concept is followed here.

Specimens examined:

INDIA. Kerala: Trivandrum, Joseph 44615A (MH); Tamil Nadu: Nilgiris, Bor s.n. (DD); Collector? s.n. (MH, acc. no. 50115). Salem, Rao $18268(\mathrm{MH})$.

\section{Oberonia falconeri Hooker f. - Fig. 25.}

Oberonia falconeri Hooker f., Icon. (1888) t. 1780; Fl. Brit. India 5 (1888) 678; Santapau \& Kapadia, Orch. Bombay (1966) 65; Seidenf., Dansk Bot. Ark. 25 (3) (1968) 35; ibid. 33 (1) (1978) 22; Pradhan, Indian Orch. 2 (1979) 198; Ansari et al., J. Econ. Tax. Bot. 3 (1982) 115; Jain \& Mehrotra, Prel, Inv. Orch. India (1984) 96. - T y p e: Falconer 1008 (CAL).

Mostly erect epiphytes, acaulescent. Leaves articulate at base, up to 8 by $1.3 \mathrm{~cm}$, oblonglanceolate, acute. Scape indistinct. Spike up to $15 \mathrm{~cm}$ long. Flowers pedicelled, $2.5 \mathrm{~mm}$ long, $1.25 \mathrm{~mm}$ across, greenish-orange yellow or rusty brown, scattered on the rachis. Bracts longer than the pedicel and ovary, 3 by $1 \mathrm{~mm}$, lanceolate, acuminate, lacerate along margins. Sepals \& petals dissimilar, reflexed, sparsely gland-dotted especially towards the tip; sepals subsimilar, 1 by $0.5 \mathrm{~mm}$, ovate or obliquely ovate, acute, entire; petals 1 by 0.25 $\mathrm{mm}$, oblong or linear, subacute. Lip antrorse, quadrate in outline, 3-lobed, $1.5 \mathrm{~mm}$ long, $0.75 \mathrm{~mm}$ across lateral lobes and $0.5 \mathrm{~mm}$ across midlobe, gland-dotted; lateral lobes rounded, auricular, spreading in flower; midlobe oblong, 2-lobuled; lobules ovate-ligulate, acute, entire, parallel to each other, sinus deep, with a triangular protuberance; disc oblong-ovate, cushion-like. Ovary \& pedicel $1.25 \mathrm{~mm}$ long. Column $0.3 \mathrm{~mm}$ long, $0.45 \mathrm{~mm}$ thick, globose; clinandrium apical, orbicular, not winged; operculum $0.23 \mathrm{~mm}$ long, $0.3 \mathrm{~mm}$ broad, ovate, acute at apex; rostellum not prominent, obtuse; stigma semiorbicular; pollinia 0.23 by $0.12 \mathrm{~mm}$, oblong-obovoid.

E c o 10 g y. Flowering August-September. Altitude 500-2000 m.

D i s tribu ti on. India (Andhra Pradesh, Assam, Bihar, Madhya Pradesh, Maharashtra, Orissa, Sikkim, West Bengal), Malaya, Thailand, Vietnam. 
Specimens examined:

INDIA. Andhra Pradesh: Cherukonda, Subba Rao 28161 (MH). Assam: Jowai, Deka s.n. (ASSAM, acc. no. 32629). Bihar: Panigrahi 11726 (CAL). Locality ?: Falconer 1008 (CAL, type). Madhya Pradesh: Nair 26331 (BSA). Maharashtra: Billore 113908 (BSI). Orissa: Sambalpur, Mooney 3797 (DD). Uttar Pradesh: Arora 50025 (CAL, BSD); W. Bengal: Cambbell s.n. (CAL, acc. no. 449588).

\section{Oberonia pyrulifera Lindley - Fig. 26.}

Oberonia pyrulifera Lindley, Fol. Orch. Oberon. (1859) 3; Hooker f., Fl. Brit. India 5 (1888) 678; King \& Pantling, Ann. Roy. Bot. Gard. Calcutta 8 (1898) 14, Pl. 16B; Seidenf., Dansk Bot. Ark. 25 (3) (1968) 38; ibid. 33 (1) (1978) 23; Jain \& Mehrotraz, Prel. Inv. Orch. India (1984) 98; Kataki, Orch. Meghalaya (1986) 25. - T y p e: Griffith s.n., Myrung, Assam (K).

Oberonia verticillata var. khasiana Lindley, Fol. Orch. Oberon. (1859) 3. - T y p e: Hooker f. \& Thomson 118, Bor Pance, Khasia (K).

Epiphytes, usually erect, acaulescent. Leaves articulate at base, up to 4 by $0.5 \mathrm{~cm}$, linear, acute. Scape up to $2 \mathrm{~cm}$ long, terete. Spike up to $6 \mathrm{~cm}$ long. Flowers pedicelled, $2 \mathrm{~mm}$ long, $1 \mathrm{~mm}$ across, pale or orange yellow, scattered on the rachis. Bracts equalling the pedicel and ovary, 1 by $0.5 \mathrm{~mm}$, ovate, acuminate, lacerate along margins, gland-dotted. Sepals \& petals dissimilar, reflexed, gland-dotted; sepals similar, 0.75 by $0.5 \mathrm{~mm}$, ovate, acute, induplicate; petals 0.75 by $0.25 \mathrm{~mm}$, linear, obtuse, subentire. Lip antrorse, quadrate or cuneate in outline, indistinctly 3 -lobed, $1 \mathrm{~mm}$ long, $0.5 \mathrm{~mm}$ across lateral lobes and $1 \mathrm{~mm}$ across midlobe, gland-dotted; lateral lobes rounded and auricular, bend upwards in flower; midlobe cuneate, deeply 2-lobuled; lobules oblong or ligulate, acute, entire, diverging; sinus broad and cuneate, without any protuberance; disc indistinct. Ovary \& pedicel $1 \mathrm{~mm}$ long. Column $0.27 \mathrm{~mm}$ long, $0.33 \mathrm{~mm}$ thick, globose; clinandrium apical, orbicular, not winged; operculum $0.23 \mathrm{~mm}$ long, $0.24 \mathrm{~mm}$ broad, suborbicular, acute at apex; rostellum triangular, acute; stigma semiorbicular or lunate; pollinia 0.18 by $0.12 \mathrm{~mm}$, obovoid.

E c o lo g y. Flowering September-October. Altitude 300-2000 m.

Dis tribution. India (Assam, Manipur, Meghalaya), Bhutan, China, Thailand.

Specimens examined:

INDIA. Sikkim: Tropical Valley, Pantling 191 (CAL).

\section{Oberonia caulescens Wall. ex Lindley - Fig. 27.}

Oberonia caulescens Wall. ex Lindley, Gen. \& Sp. Orch. (1830) 15; Fol. Orch. Oberon. (1859) 7; Hooker f., F1. Brit. India 5 (1888) 682; King \& Pantling, Ann. Roy. Bot. Gard. Calcutta 8 (1898) 13B (quoad nom.); Seidenf., Dansk Bot. Ark. 25 (3) (1968) 36; Jain \& Mehrotra, Prel. Inv. Orch. India (1984) 95; Kataki, Orch. Meghalaya (1986) 25. - T y p e: Wallich 1950, Nepal (K).

Oberonia longilabris King \& Pantling, J. As. Soc. Bengal 64 (1895) 330; Ann. Roy. Bot. Gard. Calcutta 8 (1898) 13, pl. 13A. - T y p e: Pantling 227, Sunail, Sikkim (CAL).

Oberonia auriculata King \& Pantling, Ann. Roy. Bot. Gard. Calcutta 8 (1898) 13, pl. 16A; Seidenf., Dansk Bot. Ark. 25 (3) (1968) 73; Jain \& Mehrotra, Prel. Inv. Orch. India (1984) 94. - T y p e: Pantling 166, Song Chongloo, Sikkim, July, 1897 (CAL).

Mostly erect epiphytes, caulescent or not; stem often elongated up to $3.5 \mathrm{~cm}$ long. Leaves articulate at base, up to 7 by $0.5 \mathrm{~cm}$, linear, ensiform, acute or subacuminate; uppermost one much narrow. Scape up to $3 \mathrm{~cm}$ long, terete. Spike up to $9 \mathrm{~cm}$ long. Flowers pedicelled, $2.25-3 \mathrm{~mm}$ long, $1.25 \mathrm{~mm}$ across, brownish yellow, in verticils or scattered on the 
rachis. Bracts longer than the pedicel and ovary, 2.75 by $0.75 \mathrm{~mm}$, lanceolate, acuminate or subulate at apex, subentire along margins, sparsely gland-dotted. Sepals \& petals dissimilar, sparsely gland-dotted; sepals dissimilar, reflexed; dorsal sepal 0.75 by $0.5 \mathrm{~mm}$, oblong, obtuse, entire; lateral sepals 1 by $0.5 \mathrm{~mm}$, ovate, acuminate, entire and decurved along margins; petals 0.75 by $0.25 \mathrm{~mm}$, linear, subacute, subentire, spreading in flower. Lip antrorse, quadrate in outline, 3-lobed, $1.5 \mathrm{~mm}$ long, $0.75 \mathrm{~mm}$ across both lateral lobes and midlobe, gland-dotted; lateral lobes rounded and auricular, minute, bend upwards in flower; midlobe cuneate, deeply 2-lobuled; lobules triangular, acute, entire, diverging; sinus broad and cuneate, with a minute protuberance; disc indistinct. Ovary \& pedicel $1.25-$ $1.75 \mathrm{~mm}$ long. Column $0.36 \mathrm{~mm}$ long, $0.53 \mathrm{~mm}$ broad, with 2 lateral wings; clinandrium apical, suborbicular, not winged; operculum $0.23 \mathrm{~mm}$ long, $0.3 \mathrm{~mm}$ broad, ovate, truncate at apex; rostellum triangular, acute; stigma lunate; pollinia 0.17 by $0.14 \mathrm{~mm}$, obovoid.

E c o $\log$ y. Flowering July-August. Altitude $1200-2500 \mathrm{~m}$.

Dis tribution. India (Meghalaya, Nagaland, Sikkim, Uttar Pradesh), Bhutan, China, Nepal, Taiwan.

N o t e. The plants of Oberonia caulescens often exhibit a caulescent nature due to the elongated leaf-bases, but this character is not constant in all the specimens examined. The species $O$. caulescens sensu King \& Pantling (1898) is actually $O$. mannii Hooker f. (vide Seidenfaden, 1.c.).

Specimens examined:

INDIA. Meghalaya: K. \& J. Hills, Sharma 20315 (ASSAM). Nagaland: Bahadur 55747 (ASSAM). Sikkim: Song Chongloo, Pantling 166 (CAL, type of $O$. auriculata). Sunail, Pantling 227 (CAL, type of O. longilabris). Uttar Pradesh: Dafica, Arora 66185 (BSD). Shandev, Arora 33821 (BSD).

\section{SECTION $\mathrm{V}$}

28. Oberonia bicornis Lindley - Fig. 28.

Oberonia bicornis Lindley, Gen. \& Sp. Orch. (1830) 16; Fol. Orch. Oberon. (1859) 4; Hooker f., Fl. Brit. India 5 (1888) 682; Santapau \& Kapadia, Orch. Bombay (1966) 73; Seidenf., Dansk Bot. Ark. 25 (3) (1968) 85; Pradhan, Indian Orch. 2 (1979) 199; Manilal \& Kumar, J. Econ. Tax. Bot. 4 (1983) 987; Jain \& Mahrotra, Prel. Inv. Orch. India (1984) 95; Kataki et al., Threat. End. Orch. (1984) 68; Kataki, Orch. Meghalaya (1986) 26. - T y p e: Wallich 1949, Sillet, Indiae Orientalis (K).

Oberonia umbonata Blatt. \& McCann, J. Bombay Nat. Hist. Soc. 35 (1931) 259. - T y p e: Bell \& Sedgwick 7270, Siddhapur, N. Kanara, $1400 \mathrm{ft}$. (BLAT).

Oberonia tenuis auct. non Lindley (1859); Santapau \& Kapadia, Orch. Bombay (1966) 74; Henry \& Swaminathan, Indian J. Forestry 5 (1) (1982) 79; Manilal \& Kumar, J. Econ. Tax. Bot. 4 (1983) 988.

Pendulous or erect epiphytes, acaulescent. Leaves not articulate, up to 6 by $0.5 \mathrm{~cm}$, linear-oblong, acute and apiculate at apex; uppermost one much reduced. Scape indistinct or up to $0.5 \mathrm{~cm}$ long, terete. Spike up to $10 \mathrm{~cm}$ long. Flowers pedicelled, $1.75-3 \mathrm{~mm}$ long, 1-2.25 mm across, orange-red, in verticils $2.5-3 \mathrm{~mm}$ apart on the rachis or the upper and lower ones imbricated. Bracts longer than the pedicel and ovary, 1.25-3 by $0.25-0.5 \mathrm{~mm}$, lanceolate, acuminate, entire. Sepals \& petals dissimilar, spreading in flower; sepals dissimilar, gland-dotted; dorsal sepal $1-1.5$ by $0.25-0.75 \mathrm{~mm}$, lanceolate, acuminate, entire; lateral sepals much shorter than the dorsal one, $0.5-0.75$ by $0.5-0.75$ $\mathrm{mm}$, suborbicular or obliquely ovate, subacuminate, subentire; petals $0.75-1.25$ by 0.25 $\mathrm{mm}$, elliptic or linear, acute, subentire. Lip 3-lobed, 1-1.5 mm long, $0.75-1.25 \mathrm{~mm}$ 
across; lateral lobes $0.75-1.25 \mathrm{~mm}$ long, $0.25 \mathrm{~mm}$ broad, linear, acute, entire, bend upwards round the column with the tips diverging, erect or incurved; midlobe broadly cuneate, gland-dotted, indistinctly 2-lobuled; lobules ovate-triangular, acute, subentire, curved upwards in flower, with an indistinct or triangular protuberance in between; disc crescentshaped, narrow, cushion-like, running to the base of the lateral lobes. Ovary \& pedicel $1.25 \mathrm{~mm}$ long. Column $0.35 \mathrm{~mm}$ long, $0.38 \mathrm{~mm}$ thick, semi-globose; clinandrium dorsal, orbicular, not winged; operculum $0.27 \mathrm{~mm}$ long, $0.38 \mathrm{~mm}$ broad, laterally elongated oblong or quadrangular, acute at apex; rostellum minute, triangular; stigma orbicular, equalling to the clinandrium; pollinia 0.27 by $0.14 \mathrm{~mm}$, obovoid or clavate.

E c o log y. Flowering August-November. Altitude 500-1300 m.

D i s t r i b u t i o n. India (Assam, Kerala, Maharashtra, Meghalaya, Tamil Nadu). Endemic to India.

N o te. Lindley (1859) while establishing the species Oberonia tenuis considered it to be different from his earlier (1830) species $O$. bicornis by the linear petals and filiform, incurved lateral lobes as against the ovate petals and linear-lanceolate, erect lateral lobes of $O$. bicornis. Oberonia bicornis is an Indian species whereas $O$. tenuis was believed to be endemic to Sri Lanka until Santapau \& Kapadia (1966) reported it from North Kanara. Subsequently Henry \& Swaminathan (l.c.) and Manilal \& Sathish Kumar (l.c.) recorded wider distribution for the species in Western Ghats. The specimen studied by Henry \& Swaminathan on examination is now found to be matching with the description of $O$. bicornis except for the elliptic petals. We could also study a few specimens identified as $O$. tenuis from the collection of Sathish Kumar, who kindly sent it to us, but could not find any difference from the above specimen of Henry except for the smaller size of flowers and the incurved lateral lobes of lip in most of the flowers (both erect and diverging lateral lobes were noted in flowers of the same spike). From the above observations we came to the following conclusions:

a) The petals are elliptic or linear in $O$. bicornis. In the drawing of Seidenfaden (l.c.) from Wallich's specimen also the petals are not represented as ovate.

b) The incurved and diverging lateral lobes of the lip is not a constant and contrasting character for delimiting these species.

c) Considering the above two aspects, $O$. tenuis can be treated as conspecific with $O$. bicornis. However, since both species were established by the same author and the types could not be examined (only microfiche seen), it will not be appropriate to take such a final decision at this instance. We are fully convinced that all Indian specimens, earlier kept under the name $O$. tenuis, are only $O$. bicornis.

Specimens examined:

INDIA: Assam: Lushai hills, Deb 31485 (ASSAM). Kerala: Trivandrum, Sathish Kumar 509 (TBGT); Rajappan 36 (UCT). Tamil Nadu: Upper Kodayar, Henry 49663 (MH).

\section{SECTION VI}

KEY TO THE SPECIES OF SECTION VI

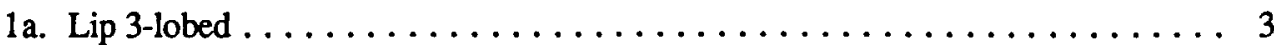

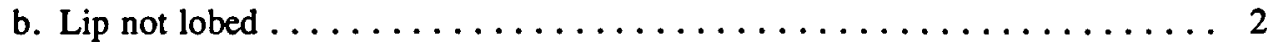


2a. Bracts suborbicular, lip suborbicular with two minute protuberances at apex; rostellum tooth-like; operculum broader than long 29. O. proudlockii King \& Pantling

b. Bracts oblong to lanceolate; lip ovate, without any protuberance at the apex; rostellum quadrate; operculum longer than broad ..... 30. O. prainiana King \& Pantling

3a. Plants caulescent with the internodes of all the leaves elongated almost uniformly. 12

b. Plants acaulescent or the internodes of the upper leaves alone elongated at times . 4

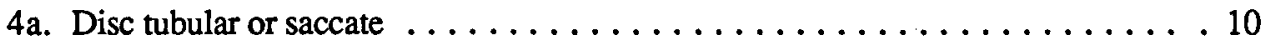

b. Disc indistinct, concave or with a cushion-like band $\ldots \ldots \ldots \ldots \ldots \ldots$

5a. Midlobe of lip distinctly 2 -lobuled with a deep sinus $\ldots \ldots \ldots \ldots \ldots$

b. Midlobe of lip obscurely 2-lobuled with a shallow sinus or not lobuled $\ldots \ldots 6$

6a. Lip quadrate in outline; lateral lobes subentire along margins; sepals minutely papillose outside ................ 0. emarginata King \& Pantling

b. Lip ovate or semiorbicular in outline; lateral lobes dentate along margins; sepals not

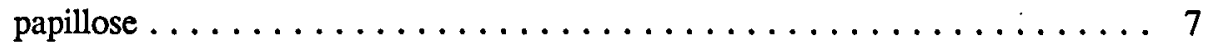

7a. Inflorescence truncate; disc of lip indistinct; petals dentate along margins.

32. O. brachystachys Lindley

b. Inflorescence not truncate; disc of lip obovate or orbicular; petals subentire ... 8

8a. Leaves oblong; bracts much longer than the pedicel and ovary, ovate-suborbicular, obtuse; midlobe of lip suborbicular; disc with a crescent-shaped cushion-like band.

33. O. pachyphylla King \& Pantling

b. Leaves linear; bracts equalling the pedicel and ovary, lanceolate, acuminate; midlobe of lip quadrate or oblong; disc concave and without any cushion-like band.

34. O. jenkinsiana Griff. ex Lindley

9a. Lateral lobes of lip spreading in flower, dentate; petals dentate along margins.

35. O. brachyphylla Blatt. \& McCann

b. Lateral lobes of lip curved upwards in flower, subentire; petals subentire along mar-

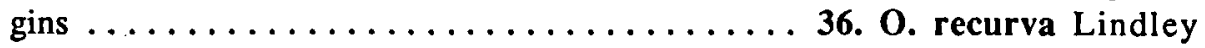

10a. Flowers in verticils on the rachis; bracts serrate or subentire; column winged laterally; disc of lip tubular . . . . . . . . . . . . . . . . . . . 11

b. Flowers scattered on the rachis; bracts entire; column not winged; disc of lip ovate, saccate $\ldots \ldots \ldots \ldots \ldots \ldots \ldots \ldots \ldots$ 37. 0 . Iongibracteata Lindley

11a. Lateral lobes of lip linear or subulate; wings of column lacerate, spreading; clinandrial wings with four subulate teeth; bracts dimorphous, the lower sterile ones with long subulate apex................. 0 . rufilabris Lindley

b. Lateral lobes of lip ovate or triangular; wings of column entire, curved downwards; clinandrial wings entire; bracts unimorphous ...... 38. O. obcordata Lindley 
12a. Petals linear, $0.25 \mathrm{~mm}$ broad, reflexed in flower; inflorescence $6-14 \mathrm{~cm}$ long. 40. O. falcata King \& Pantling

b. Petals ovate, $0.5 \mathrm{~mm}$ broad, spreading in flower; inflorescence up to $5 \mathrm{~cm}$ long.

41. O. mannii Hooker f.

29. Oberonia proudlockii King \& Pantling - Fig. 29.

Oberonia proudlockii King \& Pantling, J. As. Soc. Bengal II, 66 (1897) 580; Santapau \& Kapadia, Orch. Bombay (1966) 64; Seidenf., Dansk Bot. Ark. 25 (3) (1968) 22; Pradhan, Indian Orch. 2 (1979) 696; Abraham \& Vatsala, Intr. Orch. (1981) 422; Ansari et al., J. Econ. Tax. Bot. 3 (1982) 115; Joseph, Orch. Nilgiris (1982) 84; Jain \& Mehrotra, Prel. Inv. Orch. India (1984) 98. - T y p e: Proudlock 602, Near Gudalur, Nilgiri, Sept. 1896 (CAL).

Oberonia sedgwickii Blatt. \& McCann, J. Bombay Nat. Hist. Soc. 35 (1931) 257. - T y p e: Sedgwick's collector 5615, Castle Rock, W. Ghats, $1600 \mathrm{ft}$. (BLAT).

Erect or pendulous epiphytes, acaulescent. Leaves not articulate, up to 2.5 by $1 \mathrm{~cm}$, ovate-oblong, acute. Scape up to $2 \mathrm{~cm}$ long, terete. Spike up to $7 \mathrm{~cm}$ long. Flowers minutely pedicelled, $1 \mathrm{~mm}$ long, $0.75 \mathrm{~mm}$ across, pale or greenish yellow, scattered and adpressed to the rachis giving the spike a fleshy appearance. Bracts longer than the ovary and pedicel, 0.75 by $0.75 \mathrm{~mm}$, suborbicular, obtuse, lacerate along margins, gland-dotted. Sepals \& petals dissimilar, gland-dotted, glabrous; sepals subsimilar, 0.75 by $0.5 \mathrm{~mm}$, entire; dorsal sepal ovate, acute, reflexed in flower, lateral sepals obliquely ovate, acuminate, not reflexed; petals 0.75 by $0.25 \mathrm{~mm}$, linear or oblong, acute, subentire, erect in flower. Lip antrorse, not lobed, $0.75 \mathrm{~mm}$ long, $0.75 \mathrm{~mm}$ broad, suborbicular with two minute rounded or triangular protuberances at apex, irregularly denticulate along margins, gland-dotted; disc suborbicular or obovate, cushion-like. Column $0.15 \mathrm{~mm}$ long, $0.38 \mathrm{~mm}$ thick, globose; clinandrium dorsal, orbicular, wider than the column stalk, surrounded by spreading wings, not saccate; operculum $0.17 \mathrm{~mm}$ long, $0.33 \mathrm{~mm}$ broad, laterally elongated oblong or quadrate, obtuse at apex; rostellum tooth-like; stigma suborbicular, almost equalling the clinandrium; pollinia 0.18 by $0.14 \mathrm{~mm}$, ovoid.

Ec o lo g y. Flowering January-March. Altitude 900-1300 m.

Di s t r i b u ti o n. India (Karnataka, Kerala, Maharashtra, Tamil Nadu). Endemic to Western Ghats.

N o te. Seidenfaden (1.c.) included this species under the subgenus Apotemnophyllum of Schlechter which is characterised by jointed leaves; but the articulate nature is not represented in his illustrations. We could not locate any callus formation pertaining to this jointed nature on the leaves of the specimens examined.

Specimens examined:

INDIA. Tamil Nadu: Nilgiris, Proudlock 602 (CAL, type); Vajravelu 43796 (MH).

\section{Oberonia prainiana King \& Pantling - Fig. 30.}

Oberonia prainiana King \& Pantling, J. As. Soc. Bengal II, 64 (1895) 331; Ann. Roy. Bot. Gard. Calcutta 8 (1898) 3, Pl. 1; Seidenf., Dansk Bot. Ark. 25 (3) (1968) 100; ibid. 33 (1) (1978) 35; Pradhan, Indian Orch. 2 (1979) 193; Jain \& Mehrotra, Prel. Inv. Orch. India (1984) 98. - T y p e: Pantling 225, Sivoke Valley of Teesta, $1000 \mathrm{ft}$., 1892 (CAL).

Erect or pendulous epiphytes, acaulescent. Leaves not articulate, up to 2.5 by $1 \mathrm{~cm}$, oblong-ovate, acute. Scape indistinct or up to $2 \mathrm{~cm}$ long, terete. Spike up to $9 \mathrm{~cm}$ long. 
Flowers pedicelled, $1.25 \mathrm{~mm}$ long, $0.5 \mathrm{~mm}$ across, in verticils or scattered on the rachis. Bracts equalling the pedicel and ovary, 0.75 by $0.25 \mathrm{~mm}$, oblong-lanceolate, acuminate, subentire or irregularly serrate along margins, sparsely gland-dotted. Sepals \& petals dissimilar, sepals dissimilar, entire, reflexed and circinnate in flower; dorsal sepal 0.5 by 0.25 $\mathrm{mm}$, oblong, acute; lateral sepals 0.5 by $0.5 \mathrm{~mm}$, ovate, obtuse; petals 0.75 by $0.25 \mathrm{~mm}$, oblanceolate-elliptic, obtuse, irregularly dentate along margins, reflexed in flower, glanddotted. Lip antrorse, ovate, not lobed, $0.75 \mathrm{~mm}$ long, $0.5 \mathrm{~mm}$ broad, obtuse, lacerate or irregularly dentate along margins, glabrous, gland-dotted; disc indistinct. Ovary \& pedicel $0.75 \mathrm{~mm}$ long. Column $0.23 \mathrm{~mm}$ long and thick, obovoid or subglobose; clinandrium dorsal, orbicular, winged around, saccate; operculum $0.23 \mathrm{~mm}$ long, $0.20 \mathrm{~mm}$ broad, quadrate, acute at apex; rostellum quadrate, obtuse or truncate at apex, equalling the clinandrial wing; stigma suborbicular, minute; pollinia 0.15 by $0.12 \mathrm{~mm}$, obovoid.

Ecolog y. Flowering April-June. Altitude 500-1500 m.

Dis $\mathrm{tr}$ i b u t i o n. India (Sikkim), Malaya, Thailand.

Specimens examined:

INDIA. Sikkim: Dumsong, a.c. H. 572 (BSI). Sivoke, Pantling 225 (CAL, type).

\section{Oberonia emarginata King \& Pantling - Fig. 31 .}

Oberonia emarginata King \& Pantling, Ann. Roy. Bot. Gard. Calcutta 8 (1898) 6, PI. 2A; Seidenf., Dansk Bot. Ark. 25 (3) (1968) 106; ibid. 33 (1) (1978) 37; Jain \& Mehrotra, Prel. Inv. Orch. India (1984) 95.

- T y p e: Pantling 423, Namgah, Sikkim (K, holo; AMES, BM, CAL, L, P).

Oberonia micrantha King \& Pantling, Ann. Roy. Bot. Gard. Calcutta 8 (1898) 6, Pl. 5 (non A. Rich. 1834); Pradhan, Indian Orch. 2 (1979) 200 - T y pe: Pantling 324. Tentong, Sikkim (K, holo; CAL, P).

Erect or pendulous epiphytes, acaulescent, but the internodes of the upper leaves at times elongated up to $2 \mathrm{~cm}$ long. Leaves not articulate, up to 3.5 by $0.3 \mathrm{~cm}$, linear, acute or subacuminate. Scape indistinct or up to $1 \mathrm{~cm}$ long, terete. Spike up to $7 \mathrm{~cm}$ long. Flowers subsessile, $1 \mathrm{~mm}$ long, $0.75 \mathrm{~mm}$ across, arranged in verticils about $1 \mathrm{~mm}$ apart on the rachis. Bracts longer than the pedicel and ovary, 1 by $0.5 \mathrm{~mm}$, lanceolate, acuminate, subentire. Sepals \& petals subsimilar, 0.5 by $0.4 \mathrm{~mm}$; sepals subsimilar, ovate, minutely papillose outside, spreading in flower; dorsal sepal obtuse at apex, entire; lateral sepals subacuminate, entire and induplicate; petals ovate, obtuse or acuminate, spreading or reflexed in flower. Lip antrorse, quadrate in outline, 3-lobed, 0.5-0.75 $\mathrm{mm}$ long and across both lateral lobes and midlobe, sparsely gland-dotted; lateral lobes oblong-cuneate, rounded at apex, subentire, spreading in flower; midlobe quadrate or semiorbicular, obscurely 2-lobuled at apex, subentire or irregularly toothed along margins; disc indistinct. Ovary \& pedicel $0.5 \mathrm{~mm}$ long. Column $0.3 \mathrm{~mm}$ long, $0.27 \mathrm{~mm}$ broad, cylindric or subglobose; clinandrium dorsal, orbicular, with spreading wings around, not saccate; operculum 0.17 $\mathrm{mm}$ long, $0.21 \mathrm{~mm}$ broad, laterally elongated, quadrate or oblong, acute at apex; rostellum little longer than the clinandrial wing, oblong or ovate, rounded at apex; stigma crescentshaped or semiorbicular.

E c o lo g y. Flowering July-September. Altitude about $2000 \mathrm{~m}$.

Dis tribution. India (Sikkim), Thailand.

Specimens examined:

INDIA. Sikkim: Namgah, Pantling 423 (CAL, type). Tendong, Pantling 324 (CAL, type of $O$. micrantha). 


\section{Oberonia brachystachys Lindley - Fig. 32 .}

Oberonia brachystachys Lindley, Sert. Orch. Sub. (1838) L. 8; Fol. Orch. Oberon. (1859) 4; Hooker f., Fl.

Brit. India 5 (1888) 677; Seidenf., Dansk Bot. Ark. 25 (3) (1968) 104; ibid. 33 (1) (1978) 37; Pradhan, Indian Orch. 2 (1979) 202; Jain \& Mehrotra, Prel. Inv. Orch. India (1984) 95. - T y p e: Griffith 697, 778, Burmese Empire (K, syn).

Oberonia demissa Lindley, Fol. Orch. Oberon. (1859) 4; Hooker f., Fl. Brit. Ind. 5 (1888) 680; King \&

Pantling, Ann. Roy. Bot. Gard. Calcutta 8 (1898) 9, pl. 10. - T y p e: Hooker $f .121$, Terai below Sikkim (K).

Epiphytes, mostly erect, acaulescent. Leaves not articulate, up to 6 by $1.2 \mathrm{~cm}$, oblong, acute. Scape indistinct or up to $5 \mathrm{~mm}$ long, terete. Spike up to $5 \mathrm{~cm}$ long, erect, abruptly ending in a truncate apex. Flowers pedicelled, $1.75 \mathrm{~mm}$ long, $1.25 \mathrm{~mm}$ across, pale green, arranged in verticils about $2 \mathrm{~mm}$ apart on the rachis. Bracts little longer than the pedicel and ovary, 1.5 by $0.5 \mathrm{~mm}$, lanceolate, acuminate, subentire, sparsely gland-dotted. Sepals \& petals dissimilar, spreading in flower, gland-dotted; sepals dissimilar; dorsal sepal 0.5 by $0.4 \mathrm{~mm}$, ovate, obtuse, entire; lateral sepals 0.5 by $0.75 \mathrm{~mm}$, ovate, acuminate, entire; petals 0.5 by $0.3 \mathrm{~mm}$, oblong, obtuse, dentate along margins. Lip reflexed in flower, ovate in outline, 3-lobed, $0.5 \mathrm{~mm}$ long, $0.75 \mathrm{~mm}$ across lateral lobes and $0.5 \mathrm{~mm}$ across midlobe, gland-dotted; lateral lobes cuneate, wing-like, truncate and irregularly dentate at apex, spreading in flower; midlobe quadrate, obscurely 2-lobuled at apex with a broad and shallow sinus in between; lobules semiorbicular, irregularly dentate; disc ovate, indistinct. Ovary \& pedicel $1.25 \mathrm{~mm}$ long. Column $0.3 \mathrm{~mm}$ long, $0.33 \mathrm{~mm}$ thick, cylindric-clavate; clinandrium apical, orbicular, winged around, not saccate; operculum $0.2 \mathrm{~mm}$ long, 0.3 $\mathrm{mm}$ broad, oblong or rectangular, obtuse at apex; rostellum ovate, obtuse, equalling the clinandrial wing; stigma crescent-shaped; pollinia 0.15 by $0.15 \mathrm{~mm}$, ovoid.

Ec o log y. Flowering July-October.

Di s trib ut i o n. India (Sikkim), Burma, Malaya, Thailand.

Specimens examined:

INDIA. Sikkim: Tropical valleys, Pantling 238 (CAL, MH).

\section{Oberonia pachyphylla King \& Pantling - Fig. 33.}

Oberonia pachyphylla King \& Pantling, Ann. Roy. Bot. Gard. Calcutta 8 (1898) 5, pl. 4; Seidenf., Dansk Bot. Ark. 25 (3) (1968) 102; Pradhan, Indian Orch. 2 (1979) 200; Jain \& Mehrotra, Prel. Inv. Orch. India (1984) 97. - T y p e: Pantling 429, Salgurra near Siligiri, Jan. 1896, 900 ft. (CAL).

Erect epiphytes, acaulescent. Leaves not articulate, up to $3 \mathrm{by} 1 \mathrm{~cm}$, oblong, acute. Scape up to $2 \mathrm{~cm}$ long, terete. Spike up to $3 \mathrm{~cm}$ long. Flowers pedicelled, $1.25 \mathrm{~mm}$ long, $0.75 \mathrm{~mm}$ across, brownish red, in close verticils. Bracts longer than the pedicel and ovary, up to 1.25 by $1.25 \mathrm{~mm}$, ovate-suborbicular, obtuse, subentire, gland-dotted. Sepals \& petals dissimilar, glabrous, gland-dotted; sepals subsimilar, 0.6 by $0.5 \mathrm{~mm}$, entire; dorsal sepal ovate-suborbicular, obtuse, spreading in flower; lateral sepals obliquely ovate, acute, antrorse; petals 0.5 by $0.25 \mathrm{~mm}$, oblong-ovate, obtuse, subentire, spreading in flower. Lip antrorse, ovate in outline, 3-lobed, $0.6 \mathrm{~mm}$ long, $0.7 \mathrm{~mm}$ across lateral lobes and $0.35 \mathrm{~mm}$ across midlobe, gland-dotted; lateral lobes small and ear-like, irregularly toothed along margins, spreading in flower; midlobe suborbicular, not lobuled, obtuse, entire; disc or bicular with a crescent-shaped, cushion-like band at the distal end. Ovary \& pedicel 0.6 
$\mathrm{mm}$ long. Column $0.32 \mathrm{~mm}$ long, $0.41 \mathrm{~mm}$ wide; clinandrium dorsal, semiorbicular, surrounded by spreading wings, not saccate; operculum $0.26 \mathrm{~mm}$ long, $0.38 \mathrm{~mm}$ broad, ovate, obtuse at apex; rostellum subulate, projecting much beyond the clinandrial wing; stigma crescent-shaped; pollinia 0.21 by $0.11 \mathrm{~mm}$, obovoid.

E c o lo g y. Flowering January onwards. Altitude about $300 \mathrm{~m}$.

Dis tri bution. India (West Bengal), Thailand, Vietnam.

Specimens examined:

INDIA. West Bengal: Salgurra near Siliguri, R. Pantling 429 (CAL, type).

34. Oberonia jenkinsiana Griff. ex Lindley - Fig. 34.

Oberonia jenkinsiana Griff. ex Lindley, Fol. Orch. Oberon. (1859) 4; Hooker f., Fl. Brit. India 5 (1888) 676; King \& Pantling, Ann. Roy. Bot. Gard. Calcutta 8 (1898) 7, pl. 7; Seidenf., Dansk Bot. Ark. 25 (3) (1968) 107; ibid. 33 (1) (1978) 36; Pradhan, Indian Orch. 2 (1979) 204; Jain \& Mehrotra, Prel. Inv. Orch. India (1984) 96; Kataki, Orch. Meghalaya (1986) 24. - T y p e: Jenkins s.n., Debooro Mook, Assam (K).

Erect or pendulous epiphytes, acaulescent, but the internodes of the upper leaves at times elongated up to $3.5 \mathrm{~cm}$ long. Leaves not articulate, up to 9 by $0.5 \mathrm{~cm}$, linear, acute or obtuse. Scape indistinct or up to $1.5 \mathrm{~cm}$ long, terete. Spike up to $6.5 \mathrm{~cm}$ long, erect or curved. Flowers subsessile, $1.75 \mathrm{~mm}$ long, $1.5 \mathrm{~mm}$ across, brownish, in verticils about 1.5 $\mathrm{mm}$ apart on the rachis. Bracts equalling the pedicel and ovary, 1 by $0.5 \mathrm{~mm}$, lanceolate, acuminate, subentire or irregularly dentate along margins. Sepals \& petals dissimilar, reflexed in flower; sepals subsimilar, 0.5 by $0.4 \mathrm{~mm}$, ovate, subentire; dorsal sepal obtuse; lateral sepals subacute; petals 0.5 by $0.25 \mathrm{~mm}$, oblong, obtuse, subentire. Lip antrorse, semiorbicular in outline, 3-lobed, $0.75 \mathrm{~mm}$ long, $1.25 \mathrm{~mm}$ across lateral lobes and 0.25 $\mathrm{mm}$ across midlobe, gland-dotted; lateral lobes oblong-cuneate, truncate and dentate at apex, spreading in flower; midlobe quadrate or oblong, obscurely 2-lobuled with a shallow sinus or entire; disc obovate, concave. Ovary \& pedicel $1 \mathrm{~mm}$ long. Column $0.38 \mathrm{~mm}$ long and thick, clavate or subglobose; clinandrium apical, orbicular, minutely winged around, not saccate; operculum $0.23 \mathrm{~mm}$ long, $0.33 \mathrm{~mm}$ broad, laterally elongated, oblong or rectangular, acute at apex; rostellum triangular, obtuse, almost equalling the clinandrial wing; stigma elliptic; pollinia 0.15 by $0.14 \mathrm{~mm}$, obovoid-globose.

E c o lo g y. Flowering September-November. Altitude 400-1200 m.

Di s tribution. India (Sikkim, Assam), Burma, China, Thailand.

Not e. Seidenfaden (1968) after examining the specimen Pantling 185 available at BM, G, K \& P wrote that it is a mystery which plant King \& Pantling (l.c.) have used for their plate 7. On the sheet Pantling 185 in Calcutta (CAL) herbarium (which Seidenfaden could not examine) a note is attached which reads: 'specimen from which the drawing was made'. Illustrations for the present work are made from the above specimen. By the distantly placed verticillate flowers of the spike, this plant can better be placed with Oberonia rasmussenii of Seidenfaden (Bot. Tidsskr. 70, 1975, 79; Dansk Bot. Ark. 33, 1978, 36); but since the difference between these plants is meagre, the original identity by the collector is retained.

Specimens examined:

INDIA. Sikkim: Valley of Teesta, Pantling 185 (CAL). 
Oberonia brachyphylla Blatt. \& McCann in J. Bombay Nat. Hist. Soc. 35 (1931) 257; Santapau \& Kapadia, Orch. Bombay (1966) 57; Seidenf., Dansk Bot. Ark. 25 (3) (1968) 91; Pradhan, Indian Orch. 2 (1979) 694; Abraham \& Vatsala, Intr. Orch. (1981) 416; Ansari, et al., J. Econ. Tax. Bot. 3 (1982) 114; Jain \& Mehrotra, Prel. Inv. Orch. India (1984) 95. - T y p e: Kapadia 2855 (BLAT, neotype proposed by Santapau \& Kapadia in J. Bombay Nat. Hist. Soc. 57 (1960) 255).

Erect or pendulous epiphytes, acaulescent. Leaves not articulate, up to 4 by $0.6 \mathrm{~cm}$, oblong, ensiform, acuminate. Scape up to $0.5 \mathrm{~cm}$ long, terete, adnate to the reduced uppermost leaf. Spike up to $7 \mathrm{~cm}$ long. Flowers pedicelled, $2 \mathrm{~mm}$ long, $1 \mathrm{~mm}$ across, greenishorange yellow, scattered on the rachis. Bracts shorter than the pedicel and ovary, 0.75 by $0.5 \mathrm{~mm}$, ovate-lanceolate, acuminate, subentire, gland-dotted. Sepals \& petals dissimilar, reflexed in flower, gland-dotted; sepals dissimilar; dorsal sepal 0.5 by $0.4 \mathrm{~mm}$, ovate, acute, entire; lateral sepals 0.75 by $0.5 \mathrm{~mm}$, obliquely ovate, subacuminate, entire and induplicate along margins; petals 0.5 by $0.3 \mathrm{~mm}$, oblong, obtuse, distantly dentate along margins. Lip antrorse, quadrate in outline, 3-lobed, $1 \mathrm{~mm}$ long, $0.75 \mathrm{~mm}$ across lateral lobes and $0.5 \mathrm{~mm}$ across midlobe, gland-dotted; lateral lobes cuneate and ear-like, spreading in flower, dentate; midlobe obovate, 2-lobuled; lobules oblong, obtuse and irregularly dentate at apex, parallel; sinus without any protuberance; disc obovate-orbicular, concave. Ovary \& pedicel $1 \mathrm{~mm}$ long, glabrous. Column $0.27 \mathrm{~mm}$ long, $0.3 \mathrm{~mm}$ thick, globose; clinandrium dorsal, suborbicular, winged around, saccate; operculum $0.18 \mathrm{~mm}$ long, 0.27 $\mathrm{mm}$ broad, laterally elongated oblong, obtuse at apex; rostellum ovate, acuminate; stigma suborbicular; pollinia 0.15 by $0.09 \mathrm{~mm}$, obovoid.

E c o l o g y. Flowering January-April. Altitude $500-700 \mathrm{~m}$.

Dis trib u ti o n. India (Maharashtra, Kerala). Endemic to Western Ghats.

Specimens examined:

INDIA. Kerala: Idukki, Sharma 43932 (MH). Palghat, Nair 56781 (MH). Trivandrum, Vatsala s.n. ('KVM', acc. no. nil).

\section{Oberonia recurva Lindley - Fig. 36.}

Oberonia recurva Lindley in Bot. Reg. 25 (1839) Misc. no. 8; Fol. Orch. Oberon. (1859) 5; Hooker f., Fl. Brit. India 5 (1888) 680; Santapau \& Kapadia, Orch. Bombay (1966) 60; Seidenf., Dansk Bot. Ark. 25 (3) (1968) 95; Pradhan, Indian Orch. 2 (1979) 203; Ansari et al., J. Econ. Tax. Bot. 3 (1982) 116; Jain \& Mehrotra, Prel. Inv. Orch. India (1984) 98. - T y p e: Loddiges s.n., Bombay (K).

Oberonia setifera Lindley, Fol. Orch. Oberon. (1859) 3. - T y p e: Dalzell 38, South Konkan (K).

Oberonia parvula King \& Pantling, J. As. Soc. Bengal 64 (1895) 330. - T y p e: Pantling 203, Valley of Teesta, Sikkim (CAL).

Oberonia croftiana King \& Pantling, Ann. Roy. Bot. Gard. Calcutta 8 (1898) 7. - T y p e: Pantling 254, Tropical Valley Sikkim (CAL).

Oberonia lingmalensis Blatt. \& McCann, J. Bombay Nat. Hist. Soc. 35 (1931) 255. - Oberonia recurva Lindley var. lingmalensis (Blatt. \& McCann) Santapau \& Kapadia, J. Bombay Nat. Hist. Soc. 57 (1960) 259. - T y p e: Blatter \& Hallberg P 1681, Lingmala near Mahableshwar (BLAT).

Erect or pendulous epiphytes, acaulescent. Leaves not articulate, up to 2.5 by $0.6 \mathrm{~cm}$, linear-ensiform, acute or acuminate. Scape indistinct or up to $1 \mathrm{~cm}$ long, terete. Spike up to $7.5 \mathrm{~cm}$ long. Flowers pedicelled, $1-2 \mathrm{~mm}$ long, $0.5-1 \mathrm{~mm}$ across, brown or orange yellow, in verticils $1 \mathrm{~mm}$ apart on the rachis and closely adpressed to it. Bracts 1 by 0.5 $\mathrm{mm}$, oblong or lanceolate, acuminate, subentire. Sepals \& petals dissimilar, spreading in 
flower, gland-dotted; sepals subsimilar 0.75 by $0.5 \mathrm{~mm}$; dorsal sepal oblong or ovate, obtuse or acute, entire; lateral sepals ovate-oblong, acuminate, entire, sometimes induplicate; petals 0.75 by $0.5 \mathrm{~mm}$, oblong-ovate or oblanceolate, acute or rounded at apex, subentire. Lip antrorse, quadrate in outline, 3-lobed, $1 \mathrm{~mm}$ long, $0.75 \mathrm{~mm}$ across lateral lobes and $0.5 \mathrm{~mm}$ across midlobe, gland-dotted; lateral lobes cuneate and ear-like while spreading, curved upwards parallel to the column but not encircling it, subentire; midlobe oblong or wedge-shaped, 2-lobuled; lobules oblong-ligulate or ovate, obtuse or acute, entire or irregularly lobed, diverging or parallel; sinus narrow or broad, without any protuberance; disc obovate, concave. Ovary \& pedicel $0.75-1.25 \mathrm{~mm}$ long. Column $0.33 \mathrm{~mm}$ long, $0.27 \mathrm{~mm}$ thick, semiglobose; clinandrium dorsal, orbicular, broader than the column stalk, surrounded by spreading wings; operculum $0.21 \mathrm{~mm}$ long, $0.3 \mathrm{~mm}$ broad, laterally elongated oblong, obtuse at apex; rostellum triangular-linear, acute at apex, longer than the clinandrial wing; stigma elliptic-orbicular or oblong; pollinia 0.18 by $0.11 \mathrm{~mm}$, obovoid.

E c ol o g y. Flowering October-March. Altitude 900-2000 m.

Di s $\mathrm{t} r$ i b u t i o n. India (Maharashtra, Meghalaya, Sikkim), Bhutan, Sri Lanka, Thailand.

S pecimens ex a m in ed:

INDIA. Maharashtra: Janarthanan 72019 (BSD). Meghalaya: Nongpoh, Joseph 45631 (ASSAM). Sikkim: Tropical Valley, Pantling 254 (CAL, type of $O$. croftiana). Valley of Teesta, Pantling 203 (CAL, type of 0 . parvula).

\section{Oberonia longibracteata Lindley - Fig. 37.}

Oberonia longibracteata Lindley, Gen. \& Sp. Orch. (1830) 15; Fol. Orch. Oberon. (1859) 2; Hooker f., Fl. Brit. India 5 (1888) 678; Seidenf., Dansk Bot. Ark. 25 (3) (1968) 83; Nair et al., J. Econ. Tax. Bot. 3 (1982) 623; Jain \& Mehrotra, Prel. Inv. Orch. India (1984) 97. - T y p e: Macrae 25 (K).

Epiphytes, mostly erect, acaulescent. Leaves not articulate, up to 9 by $0.8 \mathrm{~cm}$, linearoblong, ensiform, acuminate. Scape up to $11 \mathrm{~cm}$ long, flattened, adnate to the uppermost leaf. Spike up to $8.5 \mathrm{~cm}$ long, arcuate. Flowers pedicelled, $2.5 \mathrm{~mm}$ long, $2 \mathrm{~mm}$ across, yellowish brown, scattered on the rachis. Bracts much longer than the pedicel and ovary, 4.5 by $1 \mathrm{~mm}$, linear-lanceolate, acuminate, subentire. Sepals \& petals subsimilar, entire, spreading in flower, gland-dotted; sepals subsimilar, 1 by $0.75 \mathrm{~mm}$; dorsal sepal ovatelanceolate, acute and inflexed at apex; lateral sepals ovate, acute; petals 0.75 by $0.5 \mathrm{~mm}$, oblong, acute, subentire. Lip antrorse, quadrate in outline, 3-lobed, $0.75 \mathrm{~mm}$ long, 0.75 $\mathrm{mm}$ across both lateral lobes and midlobe, gland-dotted; lateral lobes oblong-cuneate, wing-like, truncate at apex, subentire, spreading in flower; midlobe suborbicular, obscurely 2-lobuled at apex with a broad shallow sinus in between; disc ovate, saccate. Ovary \& pedicel $1 \mathrm{~mm}$ long. Column $0.3 \mathrm{~mm}$ long, $0.36 \mathrm{~mm}$ thick, globose; clinandrium apical, orbicular, winged around, saccate; operculum $0.23 \mathrm{~mm}$ long, $0.26 \mathrm{~mm}$ broad, ovateorbicular, acute at apex; rostellum triangular, acuminate; stigma crescent-shaped; pollinia 0.17 by $0.11 \mathrm{~mm}$, obovoid.

Ec o log y. Flowering September-December. Altitude about $1700 \mathrm{~m}$.

Dis tribution. India (Kerala), Sri Lanka, Vietnam.

Specimens examined:

INDIA. Kerala: Sivagiri hills, Mohanan 72814 (MH).

SRI LANKA. Locality ?, Collector ? $543(\mathrm{MH})$. 


\section{Oberonia obcordata Lindley - Fig. 38.}

Oberonia obcordata Lindley, Fol. Orch. Oberon. (1859) 7; Hooker f., Fl. Brit. India 5 (1888) 684; King \& Pantling, Ann. Roy. Bot. Gard. Calcutta 8 (1898) 9, pl. 11; Seidenf., Dansk Bot. Ark. 25 (3) (1968) 71; ibid. 33 (1) (1978) 30; Pradhan, Indian Orch. 2 (1979) 197; Jain \& Mehrotra, Prel. Inv. Orch. India (1984) 97; Kataki, Orch. Meghalaya (1986) 27. - T y p e: Hooker f. 112, above Pankaban, Sikkim (K).

Oberonia treutleri Hooker f., Icon. (1888) t. 1786 A; Fl. Brit. India 5 (1888) 683. - T y p e: Treutler 1151, Sikkim (K).

Erect or pendulous epiphytes, acaulescent, but the internodes of the upper leaves often elongated up to $3 \mathrm{~cm}$ long. Leaves not articulate, up to 5 by $0.2-0.8 \mathrm{~cm}$, linear or lanceolate, falcate, acute or subacuminate. Scape indistinct or minute, terete. Spike up to $7 \mathrm{~cm}$ long. Flowers pedicelled, $1.5 \mathrm{~mm}$ long, $1.75 \mathrm{~mm}$ across, pale or orange brown, in verticils 2-3 $\mathrm{mm}$ apart on the rachis. Bracts much longer than the pedicel and ovary, 2.5 by 0.5 $\mathrm{mm}$, lanceolate, acuminate, distantly serrate, sparsely gland-dotted. Sepals \& petals dissimilar; sepals dissimilar, 0.75 by $0.5 \mathrm{~mm}$, reflexed in flower, not gland-dotted; dorsal sepal ovate-lanceolate, acuminate, induplicate; lateral sepals oblong-ovate, acute, entire; petals 1 by $0.25 \mathrm{~mm}$, linear, obtuse, entire, spreading in flower, sparsely gland-dotted. Lip reflexed in flower, obovate in outline, 3-lobed, $1 \mathrm{~mm}$ long, $1 \mathrm{~mm}$ broad across lateral lobes, $0.75 \mathrm{~mm}$ across midlobe, gland-dotted; lateral lobes ovate or triangular, acute or obtuse, entire, spreading in flower; midlobe cuneate or obovate, 2-lobuled or emarginate at apex; lobules ovate, acute or obtuse, entire, diverging; disc tubular with an ovate or triangular opening at the proximal end. Ovary \& pedicel $0.75 \mathrm{~mm}$ long. Column $0.38 \mathrm{~mm}$ long, 0.38 $\mathrm{mm}$ thick, subglobose, winged laterally with the wings curved downwards; clinandrium apical, orbicular, minutely winged around, not saccate; operculum $0.24 \mathrm{~mm}$ long, $0.38 \mathrm{~mm}$ broad, laterally elongated oblong, retuse or obtuse at apex; rostellum like a minute protuberance, smaller than the clinandrial wings, acute; stigma suborbicular; pollinia 0.24 by $0.14 \mathrm{~mm}$, obovoid.

E c o lo g y. Flowering July-November. Altitude about $2000 \mathrm{~m}$.

Dis tribution. India (Meghalaya, Nagaland, Sikkim), Bhutan, Thailand.

Specimens examined:

INDIA. Meghalaya: Khasia, Pantling s.n. (CAL, acc. no. 449728). Nagaland: Kohima, Hynniewta 56204 (ASSAM). Sikkim: Pantling 47 (CAL).

\section{Oberonia rufilabris Lindley - Fig. 39.}

Oberonia rufilabris Lindley, Sert. Orch. (1838) t. 8A; Fol. Orch. Oberon. (1859) 5; Hooker f., Fl. Brit. India 5 (1888) 683; Seidenf., Dansk Bot. Ark. 25 (3) (1968) 88; Pradhan, Indian Orch. 2 (1979) 199; Jain \& Mehrotra, Prel. Inv. Orch. India (1984) 98. - T y p e: Griffith s.n., Mergui, Burma (K, hold, L, P).

Erect or pendulous epiphytes, acaulescent. Leaves not articulate, up to 4.5 by $1 \mathrm{~cm}$, oblong or lanceolate, acute or obtuse. Scape indistinct. Spike up to $8 \mathrm{~cm}$ long. Flowers subsessile, dark reddish brown, arranged in verticils $1 \mathrm{~mm}$ apart on the rachis. Bracts dimorphous, subentire, gland-dotted; lower ones sterile, 3 by $0.25 \mathrm{~mm}$, elliptic-lanceolate with a subulate tip; upper ones fertile, longer than the pedicel and ovary, 1 by $0.5 \mathrm{~mm}$, lanceolate, acuminate. Sepals \& petals dissimilar, reflexed in flower, sparsely gland-dotted; sepals dissimilar, 0.75 by $0.5 \mathrm{~mm}$, entire; dorsal sepal oblong, obtuse, induplicate; lateral sepals oblong-ovate, acute; petals 0.5 by $0.25 \mathrm{~mm}$, oblong-elliptic, subacute, subentire 
along margins. Lip antrorse, oblong, 3-lobed, $1.5 \mathrm{~mm}$ long, $0.5 \mathrm{~mm}$ across midlobe, gland-dotted; lateral lobes linear or subulate, spreading in flower; midlobe oblong, 2-lobuled; lobules $0.75 \mathrm{~mm}$ long, linear, diverging; disc tubular, with an orbicular opening at the proximal end. Ovary \& pedicel $0.5 \mathrm{~mm}$ long. Column $0.41 \mathrm{~mm}$ long, $0.3 \mathrm{~mm}$ thick, cylindric, minutely winged laterally at the region of the clinandrium; the wings lacerate along margins; clinandrium apical, orbicular, subsaccate, winged around; the wings with 4 subulate teeth; the two dorsal teeth longer than the ventral pair; operculum $0.3 \mathrm{~mm}$ long, $0.38 \mathrm{~mm}$ broad, ovate or suborbicular, acuminate at apex; rostellum triangular, acuminate, shorter than the clinandrial wing; stigma elliptic; pollinia 0.2 by $0.14 \mathrm{~mm}$, obovoid.

Ecolog y. Flowering December-March. Altitude about $1500 \mathrm{~m}$.

Dis tri b u ti o n. India (Assam, W. Bengal, Bihar, Orissa), Burma, Cambodia, Malaya, Nepal, Thailand, Vietnam.

S pecimens examined:

INDIA. Assam: Tura top, Panigrahi 22530 (ASSAM).

\section{Oberonia falcata King \& Pantling - Fig. 40.}

Oberonia falcata King \& Pantling, J. As. Soc. Bengal II, 64 (1895) 329; Ann. Roy. Bot. Gard. Calcutta 8 (1898) 12, pl. 14; Seidenf., Dansk Bot. Ark. 25 (3) (1968) 75; ibid. 33 (1) (1978) 30; Jain \& Mehrotra, Prel. Inv. Orch. India (1984) 96. - T y p e: Pantling 218, Shoonthang, Sikkim (K, holo; BM, CAL, G, L, P).

Mostly pendulous epiphytes, caulescent; stem $2.5-15 \mathrm{~cm}$ long; internodes $0.4-2.5 \mathrm{~cm}$ long, almost uniformly elongated. Leaves not articulate, up to 7 by $0.4 \mathrm{~cm}$, linear, falcate or straight, acuminate. Scape indistinct. Spike 6-14 cm long. Flowers pedicelled, 2.25 $\mathrm{mm}$ long, $0.75 \mathrm{~mm}$ across, in verticils $2-6 \mathrm{~mm}$ apart on the rachis. Bracts $1.25-2$ by 0.5 $\mathrm{mm}$, lanceolate or oblong-lanceolate, acuminate, irregularly and distantly dentate, sparsely gland-dotted. Sepals \& petals dissimilar, reflexed in flower, sparsely gland-dotted; sepals subsimilar, 0.75 by $0.5 \mathrm{~mm}$, oblong or ovate, obtuse or acute, induplicate or not; petals 0.75 by $0.25 \mathrm{~mm}$, linear, obtuse or subacute, entire. Lip antrorse, quadrate or cuneate in outline, 3-lobed, $1.25 \mathrm{~mm}$ long, $0.75 \mathrm{~mm}$ across lateral lobes and $1 \mathrm{~mm}$ across midlobe, gland-dotted; lateral lobes minute and auricular or subulate, incurved and pointing forwards in flower; midlobe oblong or cuneate, 2-lobuled; lobules ovate or aciculate, acute or acuminate, subentire, diverging or rarely parallel, often folded inward; disc indistinct. Ovary \& pedicel $1.25 \mathrm{~mm}$ long. Column $0.3 \mathrm{~mm}$ long, $0.38 \mathrm{~mm}$ across, globose, winged laterally; clinandrium apical, orbicular, minutely winged around, not saccate; operculum $0.24 \mathrm{~mm}$ long, $0.3 \mathrm{~mm}$ broad, ovate-suborbicular, acute at apex; rostellum triangular, acute; stigma lunate or semiorbicular; pollinia 0.18 by $0.12 \mathrm{~mm}$, obovoid.

Ecolog y. Flowering June-August. Altitude 500-3000 m.

Dis tri bu ti o n. India (Meghalaya, Sikkim), Bhutan, Malaya, Nepal, Thailand, Vietnam.

N ot e. The specimen Pantling 454 available in CAL, which was originally identified as Oberonia caulescens Lindley and cited by King \& Pantling (1898) under this species, is now determined as $O$. falcata.

S pecimens examined:

INDIA. Meghalaya: Jaintia hills, King's collector s.n. (CAL, acc. no. 449703). Sikkim: Bor's collector 407 (DD); Pantling 218 (CAL, type), 454 (CAL), s.n. (CAL, acc. no. 449697 \& 449706). 


\section{Oberonia mannii Hooker f. - Fig. 41.}

Oberonia mannii Hooker f., Icon. (1890) t. 2003; Fl. Brit. India 6 (1890) 180; Seidenf., Dansk Bot. Ark. 25 (3) (1968) 77; Pradhan, Indian Orch. 2 (1979) 197; Jain \& Mehrotra, Prel. Inv. Orch. India (1984) 97; Kataki, Orch. Meghalaya (1986) 27. - T y p e: Mann s.n., Jaintia hills, above Sylhet, $3500 \mathrm{ft}$. (K, holo; $\mathrm{CAL}$ ).

Erect or pendulous epiphytes, caulescent; stem up to $6.5 \mathrm{~cm}$ long; internodes up to 0.5 $\mathrm{cm}$ long. Leaves not articulate, up to 2 by $0.15 \mathrm{~cm}$, linear or acicular, straight or falcate, subacuminate. Scape indistinct or up to $0.5 \mathrm{~cm}$ long, terete. Spike up to $4.5 \mathrm{~cm}$ long, arcuate. Flowers pedicelled, $1.5 \mathrm{~mm}$ long, $1 \mathrm{~mm}$ across, yellow or greenish-yellow, in verticils 1-1.5 $\mathrm{mm}$ apart on the rachis. Bracts equalling the pedicel and ovary, 0.75 by $0.5 \mathrm{~mm}$, ovate-lanceolate, acuminate, irregularly dentate or serrate along margins, sparsely glanddotted. Sepals \& petals subsimilar, 0.75 by $0.5 \mathrm{~mm}$; sepals similar, ovate, obtuse, entire, reflexed in flower; petals oblong-ovate, obtuse, crenulate or serrulate along margins, spreading in flower. Lip antrorse, quadrate in outline, 3-lobed, $1 \mathrm{~mm}$ long, $0.75 \mathrm{~mm}$ across lateral lobes and midlobe, gland-dotted; lateral lobes minute, lanceolate or subulate, acuminate, incurved and pointing forward in flower, midlobe cuneate or oblong, 2-lobuled; lobules lanceolate or aciculate, acuminate, entire, diverging, curved inward or straight; disc indistinct. Ovary \& pedicel $0.75 \mathrm{~mm}$ long. Column $0.38 \mathrm{~mm}$ long and across, globose, minutely winged laterally at the region of the stigma; clinandrium apical, orbicular, minutely winged around, not saccate; operculum $0.23 \mathrm{~mm}$ long and broad, suborbicular, acute at apex; rostellum minute, triangular, acute; stigma semi-orbicular or lunate; pollinia 0.11 by $0.8 \mathrm{~mm}$, obovoid.

Ecolog y. Flowering April-October. Altitude 1000-2000 m.

Dis tribution. India (Meghalaya, Nagaland). Endemic.

S pecimens examined:

INDIA. Meghalaya: Jaintia hills, Mann s.n. (CAL, acc. no. 449647, Type); Pantling 618 (CAL). K. \& J. Hills, Deka s.n. (ASSAM, acc. No. 35357). Nagaland: Tuensang, Hynniewta 80530 (ASSAM).

\section{SPECIES NOT TREATED IN THIS STUDY}

\section{Oberonia angustifolia Lindley}

Oberonia angustifolia Lindley, Fol. Orch. Oberon. (1859) 5; Hooker f., Fl. Brit. India 5 (1888) 684; Seidenf., Dansk Bot. Ark. 25 (3) (1968) 83; Jain \& Mehrotra, Prel. Inv. Orch. India (1984) 94. T y p e: Griffith s.n., Darjeeling (K).

Dis tribution. India (Meghalaya).

Note. No specimen of this species is available in Indian herbaria. Probably an extinct species. It is believed to be allied to $O$. longibracteata, but the bracts are shorter or only slightly longer than the flowers (vide Seidenfaden, 1.c.).

\section{Oberonia anthropophora Lindley}

Oberonia anthropophora Lindley, Gen. \& Sp. Orch. (1830) 16; Fol. Orch. Oberon. (1859) 7; Seidenf., Dansk Bot. Ark. 25 (3) (1968) 93; Jain \& Mehrotra, Prel. Inv. Orch. India (1984) 94. - T y p e : Wallich 1951, Tavoy, Burma (K, holo; G). 
Dis tri b u t i o n. India ?, Burma, Thailand, Vietnam.

N ot e. Jain \& Mehrotra (1.c.) included this species while enumerating the Indian Orchids. However, there is no collection of this plant from the Indian region.

\section{Oberonia clarkei Hooker f.}

Oberonia clarkei Hooker f., Icon. (1888) t. 1779; Fl. Brit. India 5 (1888) 676; Seidenf., Dansk Bot. Ark. 25 (3) (1968) 107; Pradhan, Indian Orch. 2 (1979) 204; Jain \& Mehrotra, Prel. Inv. Orch. India (1984) 95; Kataki, Orch. Meghalaya (1986) 24. - T y p e: Clarke 5818, Shillong, Khasia (K).

$\mathrm{N}$ ot e. The type specimen at Kew (Clarke 5818) is the only known specimen of this species from India. Seidenfaden (1.c.) differentiated this species from its closely allied $O$. jenkinsiana by the smaller leaves and inflorescence. Since there is no specimen of this plant available in Indian herbaria, it is not treated here.

\section{Oberonia griffithiana Lindley}

Oberonia griffithiana Lindley, Sert. Orch. (1838) t. 8B; Seidenf., Dansk Bot. Ark. 25 (3) (1968) 70; Jain \& Mehrotra, Prel. Inv. Orch. India (1984) 96. - T y p e: Griffith s. n., Moulmein, Burma (K).

Dis tribution. India ?, Burma, Thailand.

N ot e. Jain \& Mehrotra (l.c.) included this species in their enumeration. But there is no other record of its availability in India.

\section{Oberonia orbicularis Hooker $f$.}

Oberonia orbicularis Hooker f., Fl. Brit. India 5 (1888) 677; King \& Pantling, Ann. Roy. Bot. Gard. Calcutta 8 (1898) 5; Seidenf., Dansk Bot. Ark. 25 (3) (1968) 23; Jain \& Mehrotra, Prel. Inv. Orch. India (1984) 97; Kataki, Orch. Meghalaya (1986) 25. - T y p e: Clarke 9610, at Dikkeling, Sikkim (K).

Dis tribution. India (Sikkim).

N o t e. Pradhan (1979: 194) and Kataki (l.c.) considered Oberonia orbicularis to be conspecific with $O$. pachyrachis. All specimens in the Indian herbaria which were earlier named as $O$. orbicularis are found to be identical with $O$. pachyrachis during the present study. Seidenfaden (l.c.), after examining the type at Kew, retained it as a distinct entity. According to him, the most distinguishing feature of these allied species is the compressed scape which is adnate to the uppermost leaf in $O$. pachyrachis. However, in his illustration of $O$. orbicularis, the scape is represented as compressed at the base. Due to lack of an opportunity to examine the type and for the absence of a similar specimen in the Indian herbaria, 0 . orbicularis is not included in the present work. 